\title{
Jordanian women's use of documentary programs and the fulfilment gained from them (Al-Jazeera Documentary Channels and National Geographic Abu Dhabi as examples)
}

\author{
Odai Ahmad Qaqish \\ Mohammad Hashem AL-momani
}

IPSI || University of Manouba || Tunis

\begin{abstract}
This study focuses on the use of documentaries by Jordanian woman and fulfilled goals achieved through this usage, by conducting a poll for Jordanian women in the three Jordanian regions in order to recognize the effect of these documentaries on Jordanian woman, how important these channels for her and how much she spends watching it.

The study focuses on identifying these usages through two channels, Al-Jazeera documentaries and National Geographic Abu Dhabi and it brings the light on the effects of these programs and whether it serves its goals. This study comes to guide the owners of this field to better content and bring these programs to a better level that fulfils the needs of Arabic women and especially Jordanian women. The answers to the study sample which is 300 expose the position of Jordanian women towards documentaries. The results show that $77.3 \%$ of Jordanian women watch documentaries and it fulfils their needs. Also, the results show that $72.4 \%$ of Jordanian women prefer watching National Geographic Abu Dhabi over Al-Jazeera documentaries.
\end{abstract}

keywords: Documentaries, National Geographic Abu Dhabi, Al Jazzera documentaries, Jordanian woman.

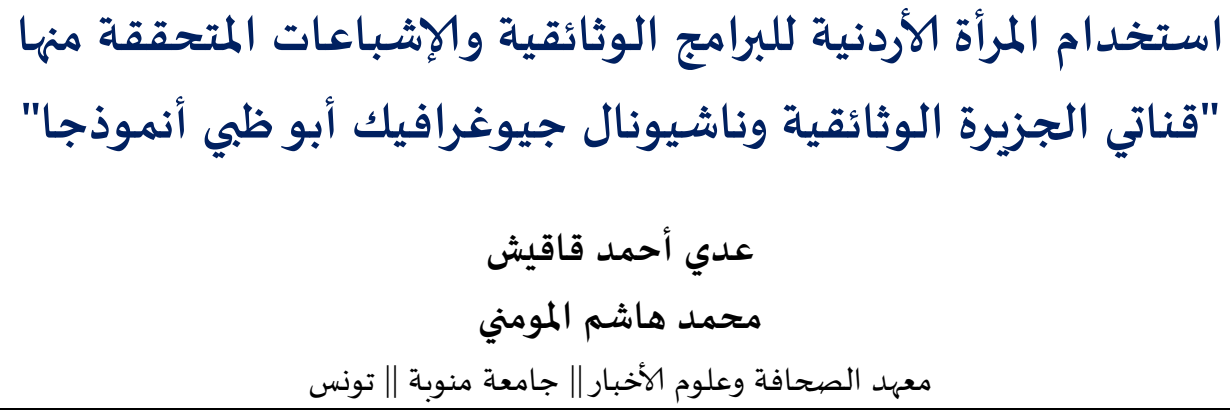

الملخص: تتناول هذه الدراسة استخدام المرأة الأردنية للبرامج الوثائقية والإشباعات المتحققة، من خلال استطلاع رأي للمرأة الأردنية في

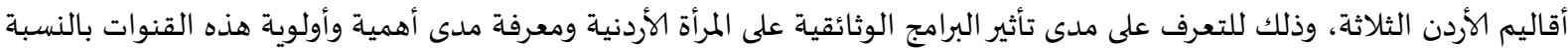

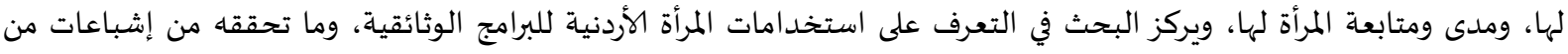

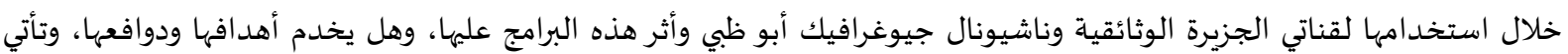
هذه الدراسة لتوجياء اصحاب هذا المجال للارتقاء في رفع مستوى هذه البرامج بما يلبي رغبة المرأة العبية عمومًا والأردنية على خصوصيا.

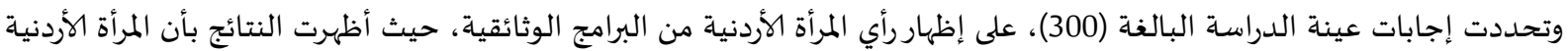
تشاهد البرامج الوثائقية بنسبة بلغت (77.3\%)، وأن البرامج الوثائقية تحقق الإشباع لدى المرأة، كما أن المرأة الأردنية تفضل مشاهداهدة قناة ناشيونال جيوغرافيك أبو ظبي بنسبة بلغت (72.4\%) على حساب قناة الجزيرة الوثائقية. 
تعد البرامج الوثائقية طريقة لاستعراض العديد من المواضيع المتنوعة التي تخاطب جميع الفئات بطريقة

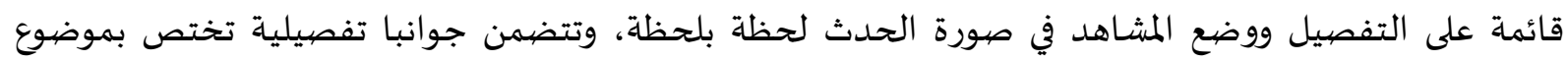
معين وكثير من المواضيع لديها روادها، فمثلا جوانب سياسية أو اجتماعية وأخرى اقتصادية ... وغيرها، تختلف

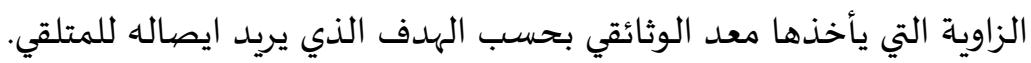

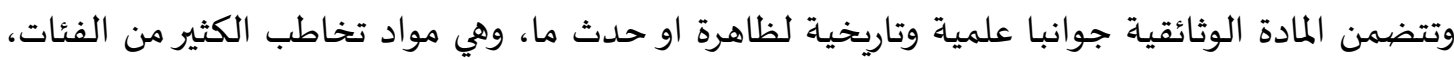

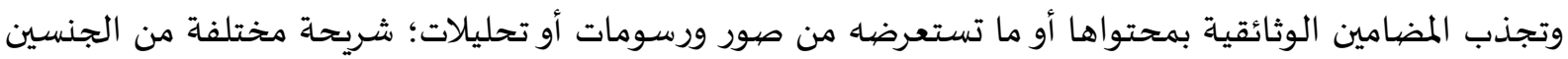

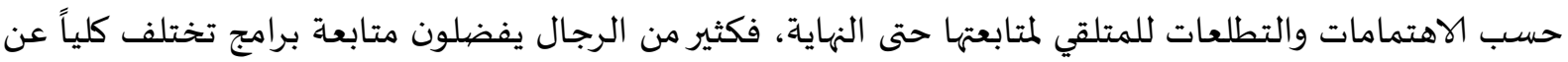
البرامج التي تفضلها المرأة والعكس كذلك. وتراعي المواد الوثائقية الموجهة للمرأة كشريحة يوجاه إلهيها الكثير من المضامين الوثائقية التي تغذي الخبرات

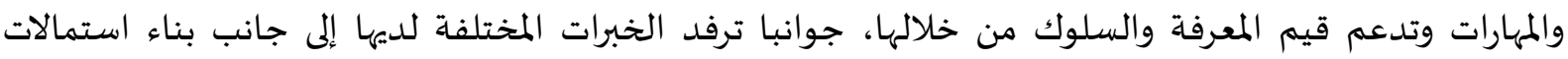
عاطفية نحو الفكرة الوثائقية الموجهة الهها، وكثير من الجوانب الوثائقية في الأردن تركز على التاريخ والحضيارة والطبيعة الجغرافية والاجتماعية والسياسية بصفة الهوتة عامة. ولذلك جاءت هذه الدراسة للبحث في استخدام المرأة الأردنية للبرامج الوثائقية وما تحققه لها من إشباعاعات

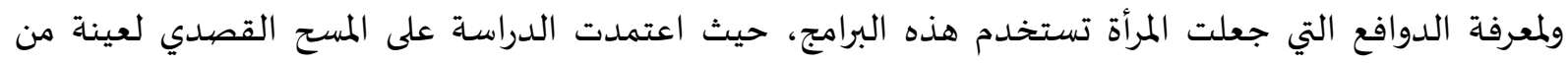
النساء الأردنيات بما يشمل جميع مناطق المملكة وأقدات المعاليمها.

مشكلـة الدراسـة: إن الدراسات التي بحثت في مدى تأثير الوثائقية على الإنسان نجحت في إعطاء المؤشرات التي تساعد في فهم

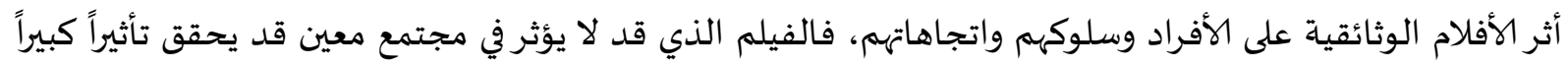

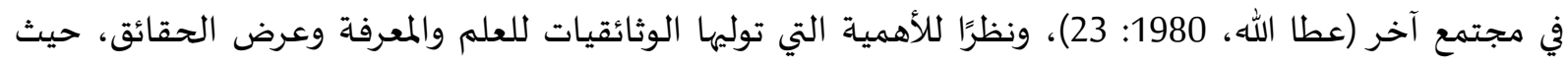

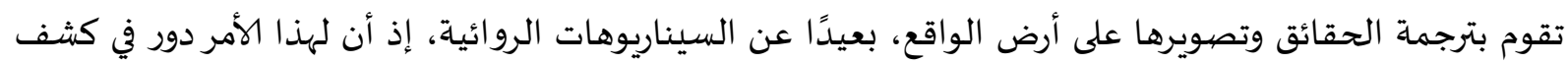
الحقائق دون تزييف أو تغيير لها. إن الكثير من الدراسات التي تطرقت لموضيوع البرامج الوثائقية لم تدرس دائ حالة المرأة في استخدامها للبرامج

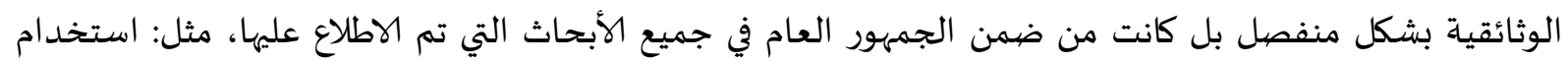

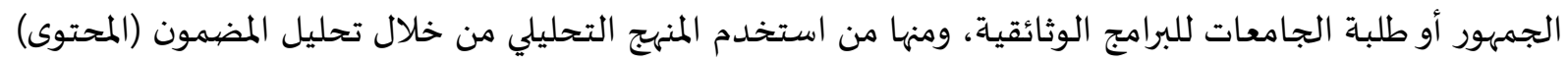

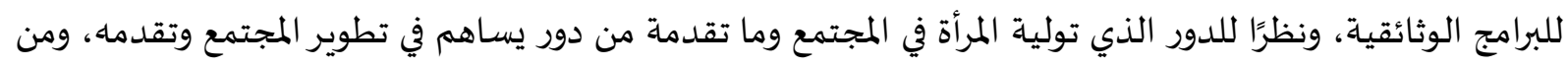

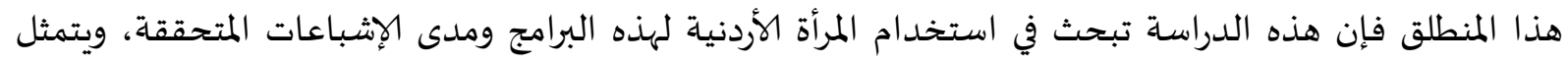

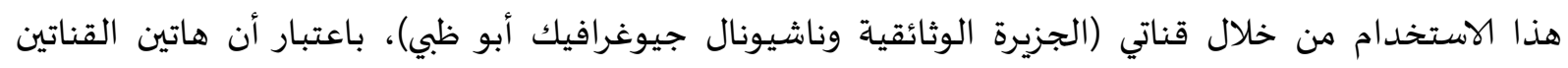
متخصصتين بالبرامج الوثائقية.

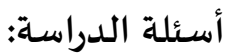

بناء على ما سبق، تتمثل مشكلة الدراسة بالتساؤل الرئيس الآتي:

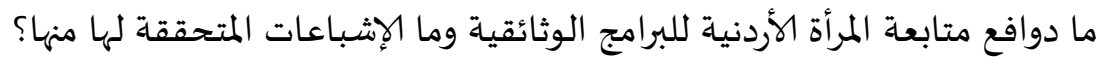


وتنبثق من السؤال الرئيس الأسئلة الفرعية الآتية:

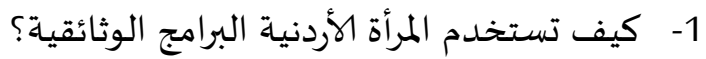

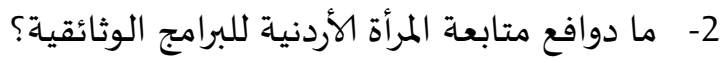

3- ما الإشباعات المتحققة لدى المرأة الأردنية من خلال متابعتها للبرامج الوثائقية؟

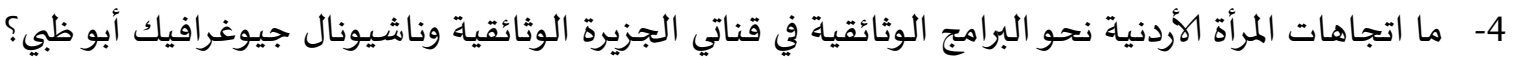

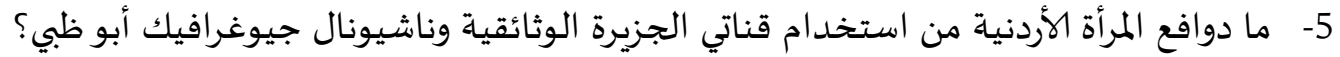

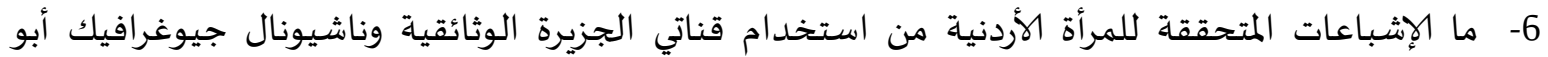

ظبي؟

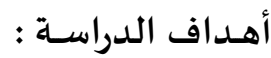

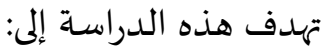

1. معرفة مدى تأثير قناتي عينة الدراسة على المبحوثات من خلال استخدامهن للبرامج الوثائقية.

2. معرفة مدى أهمية وأولوية هذه القنوات بالنسبة للمرأة الأردنية، ومدى ومتابعتهم لها.

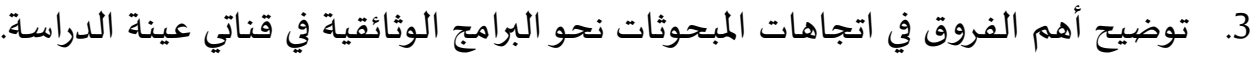

4. معرفة الإشباعات التي تحققت لدى المرأة الأردنية من خلال متابعتها للبرامج الوثائقية في قناتي عينة

الدراسة.

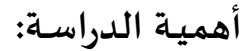

تكمن أهمية البحث في التعرف على استخدامات المرأة الأردنية للبرامج الوثائقية، وما تحققه من إشباعات

من خلال استخدامها لقناتي الجزيرة الوثائقية وناشيونال جيوغرافيك أبو ظبي، وللتعرف على أثر البرامج الوثائقية

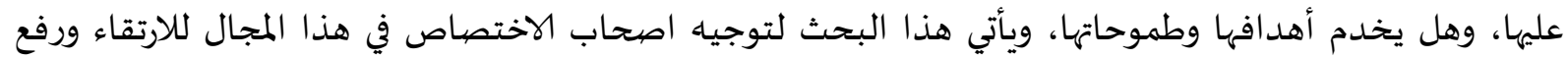

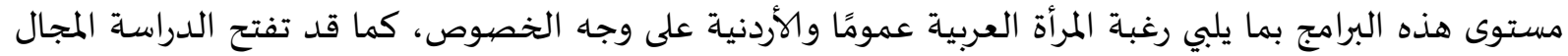

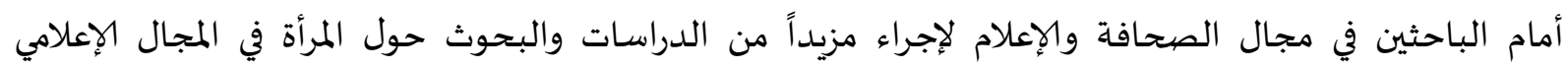
والبرامج الوثائقية تحديدًا وذلك لعدم توفر هذا النوع من الدراسات للمرأة.

حدود الدراسة

تقتصر الدراسة على الحدود الآتية:

• الحدود الموضوعية: استخدام المرأة الأردنية للبرامج الوثائقية والإشباعات المتحققة منها

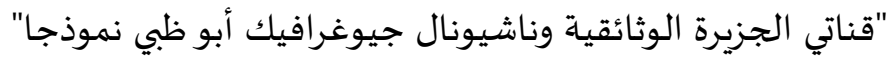

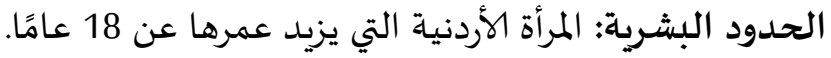

الحدود الزمانية: المتمثل بالفترة (2019/12/1 ولغاية 2020/1/30) وهي مدة توزيع الاستبانة وجمعها.

الحدود المكانية: المتمثل بمحافظات المملكة الأردنية (عمّان، الزرقاء، إربد).

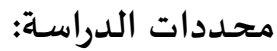

تتحدد هذه الدراسة بنتائج إجابات مجتمع الدراساة وهي المرأة الأردنية، ومن الممكن تعميم نتائجها على

المرأة الأردنية بشكل عام لأن المجتمع في الدراسة يمثل أغلب سكان المملكة. 
مصطلحات الدراسـة وتعريفاتها الإجرائية:

- - البرامج الوثائقية: إن أقرب تعريف للبرنامج الوثائقي (في إطار عملية تصنيف البرامج) هو ذلك الذي قدمه عبد

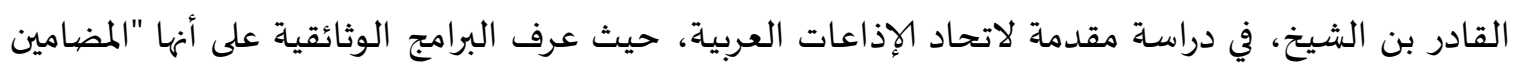

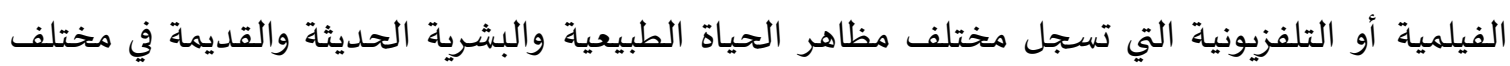

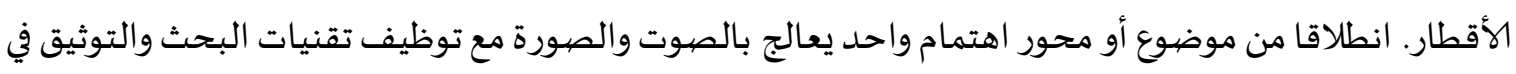

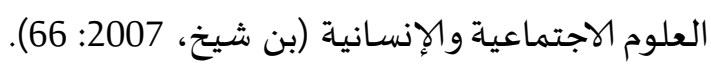

- - الفيلم الوثائقي: هو كافة أساليب التوثيق على فيلم لأي مظهر للحقيقة يتم عرضها، إما بوسائل التصوير

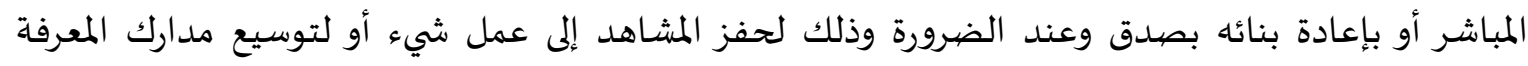

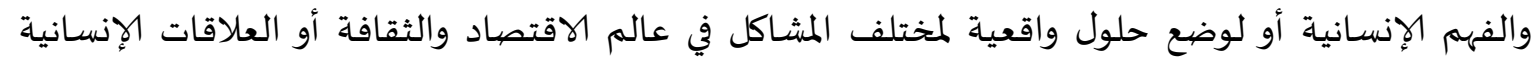

(عطالله، 1995: 12).

- - البرنامج الوثائقي (إجرائيًا): هي مادة علمية ومعرفية يتم طرحها بطريقة شيقة، تساهم في إثراء معلومات

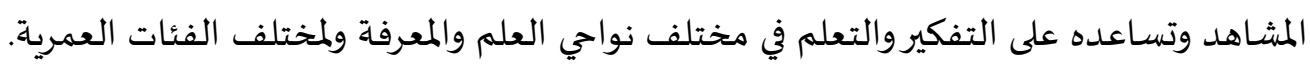

2- الإطار النظري والدراسـات السـابقة أولاًا - الإطار النظري.

نظرية الاستخدامات والإشباعات: يُعد إلياهو كاتز Katz أول من وضع اللبنة الأولى في مدخل الأستخداماتهات والإشباعات، عندما كتب مقالا عن

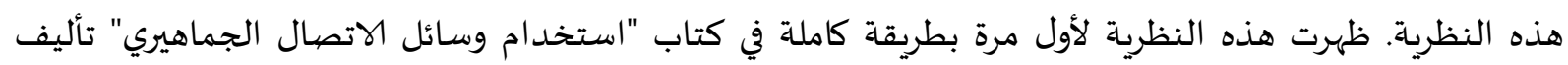
Elihu Katz and Blumler

وسائل الإعلام ومحتواها من جانب، ودوافع الفرد من التعرض إليها من جانب أخر (Werner, et al., 1992, p 250).

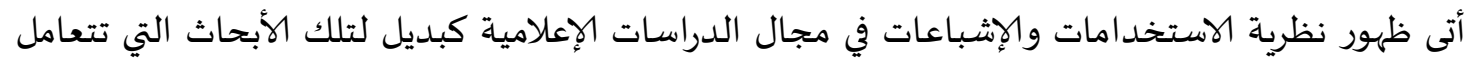

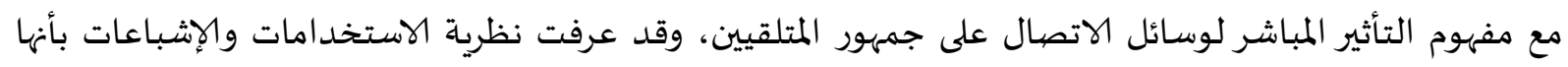

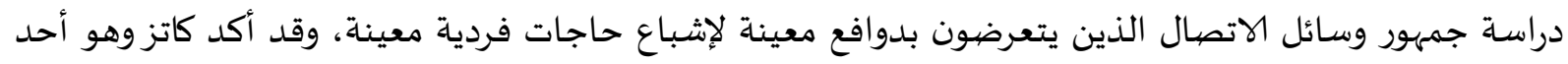
رواد هذه النظرية أن استخدام وسائل الاتصال يتضح بصورة واضحة حئه حينما نوجها اهتمامنا بما يفعله الجمهور

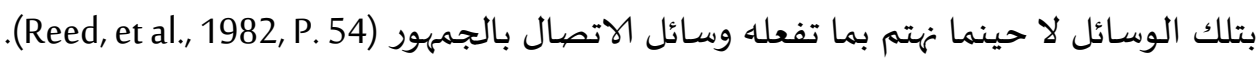

العلاقة بين الاستخدام والإشباع:

هناك اتجاهات عديدة لتفسير العلاقة بين الاستخدامات والإشباعات الذاتي منها: (العبد، والعبد، 2008: 24) اتجاه يرى أن سلوك الفرد المتمثل في مشاهدة مضمون معين، كأن يكون غير مخطط بدافع العادة.

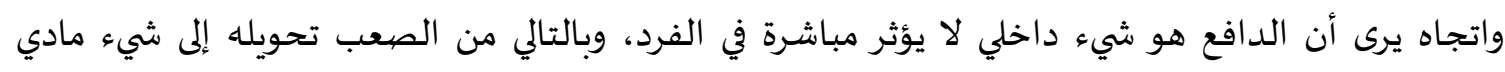
متمثل في سلوك معين. واتجاه يرى أن الدافع يؤثر بشكل مباشر في الفرد كحاجة ملحة لا تهدا إلا بعد أن يتم إشباعها. 
مدخل الحاجات والدوافع:

وتعتبر الحاجات والدوافع من العوامل المحركة للاتصال، وبصفة خاصداتة تلك الحاجات والدوافع التي يتوقع

$$
\text { الفرد أن يشبعها ويلبيها له الآخرون لتحقيق التكيف مع البيئة. }
$$

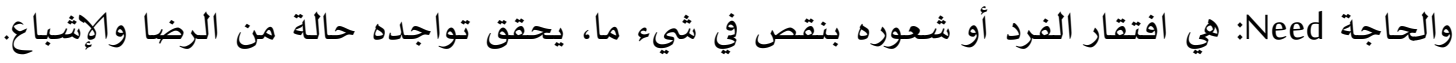

والحاجة قد تكون فسيولوجية أو نفسية.

أما الدافع Motive: فهو حاله فسيولوجية أو نفسية توجه الفرد إلى القيام بسلوك معين يقوي استجابته

إلى مثير ما. أو يشبع أو يرضي حاجة ما.

ويعتبر إشباع الحاجات وتلبية الدوافع ضرورة لدى الفرد حتى يتحقق للفرد الاتزان النفسي الذي يساعد

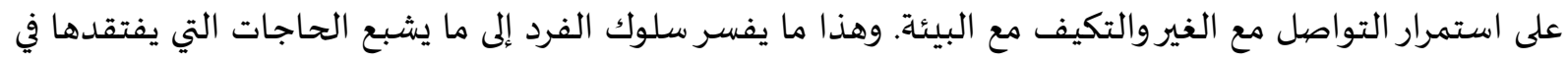

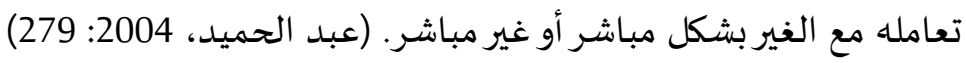

العلاقة بين والحاجات الدوافع:

تسبق الحاجات عادة الدوافع، فالحاجة تنشأ من الشعور بالنقص والحرمان من شيء ما لدى أفراد

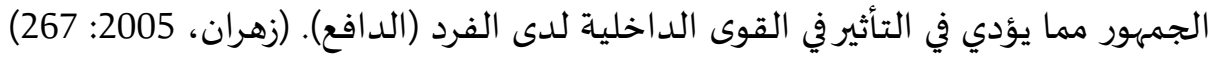

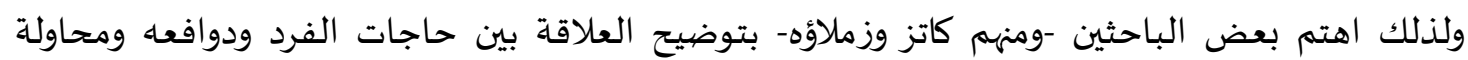

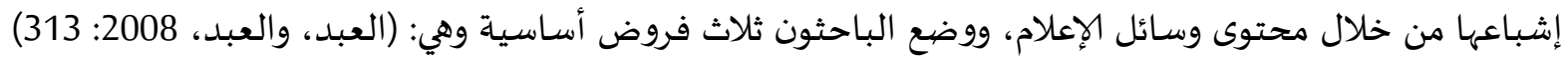

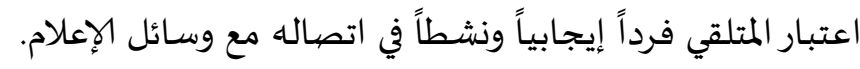

للأفراد المتلقين الحرية في الاختيار حسب الحاجة للإثباع.

التنافس بين وسائل الإعلام ومصادر أخرى حول إشباع الحاجات.

فروض النظرية:

يرى "كانز وزملاؤه" أن منظور الاستخدامات والإشباعات يعتمد على خمسة فروض، تستند عليها نظرية

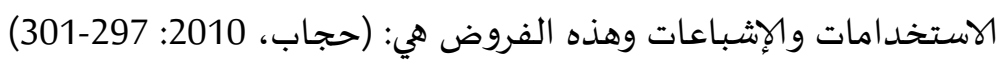

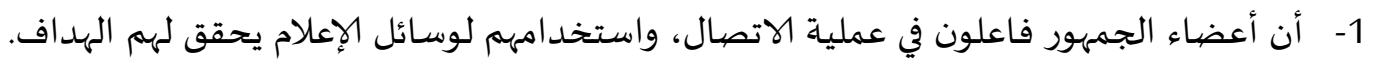

2- الربط بين الرغبة في إشباع حاجات معينة، واختيار وسيلة إعلام محددة، يرجع إلى الجمهور نفساءهاء.

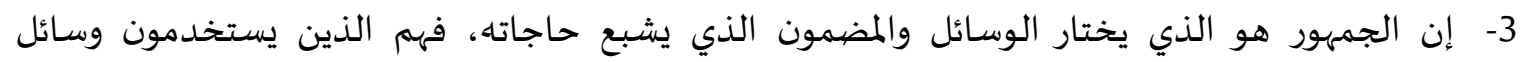

الاتصال وليست الوسائل تستخدمههم.

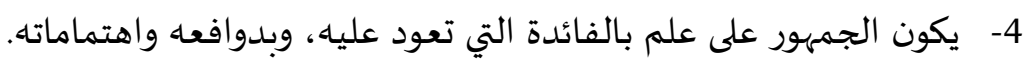

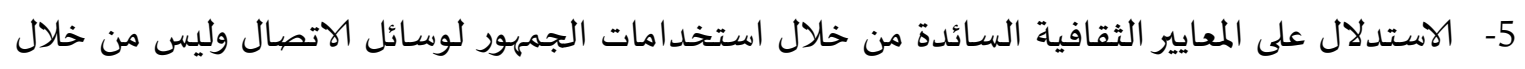

محتوى الرسائل التي تقدمها وسائل الاتصيال.

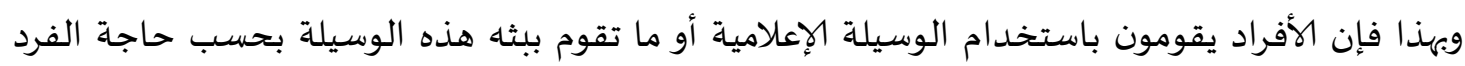

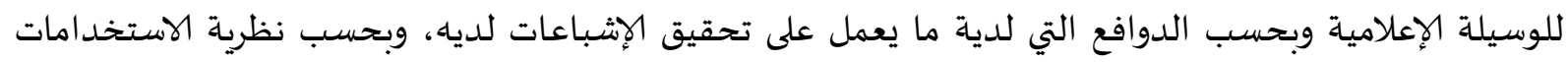

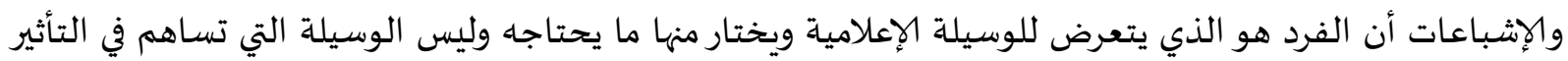
علية بشكل مباشر، فبعد التعرض وتحقيق الإشباعات لدى الفرد يمكن أن تعمل الوسيلة الإعلامية في التأثير بالفرد. 
البرنامج الوثائقي:

ظهر الفيلم الوثائقي لأول مرة عام 1912م، وكان فيلما متكاملا عن اكتشاف سكوت للقطب الجنوبي والذي

سجل الأحداث الهامة التي وقعت عام 1910 أثناء عمليات اكتشاف القطب الجنوبي وأخرجاه المخرج التهان الانجليزي

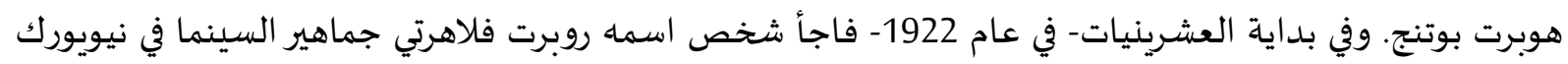

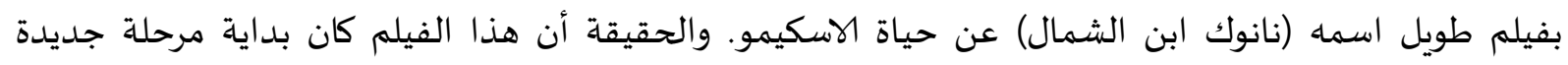

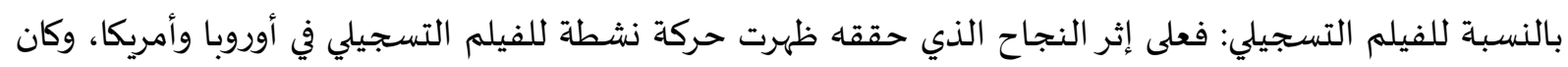

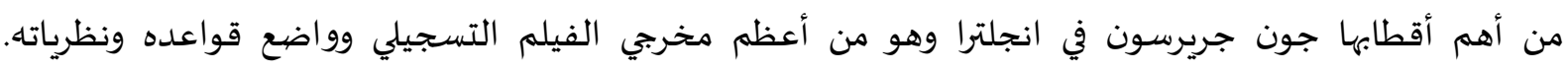
(قاقيش، 2015: من أهم: (27) وكان الفرنسيون هم أول من استخدم عبارة Film Documentaire لوصف الأفلام التي اقبل على تصيويرها

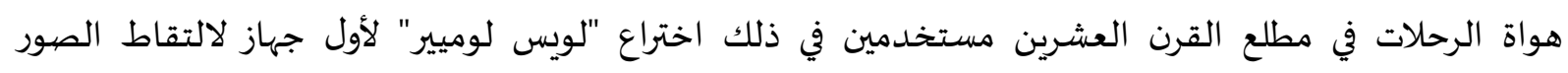

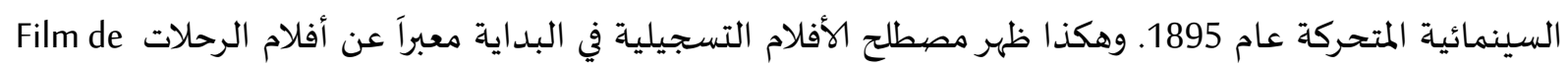

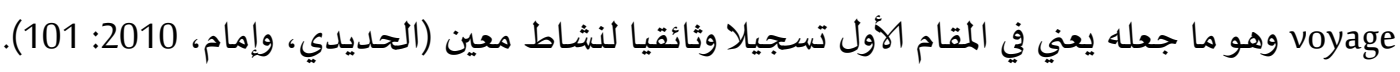

\section{مفهوم البرنامج - الفيلم الوثائقي:}

وقد جاء تعريف جريرسون للفيلم الوثائقي بأنه المعالجة الخلاقة للواقع. حيث ميزه عن غيرة من أشكال

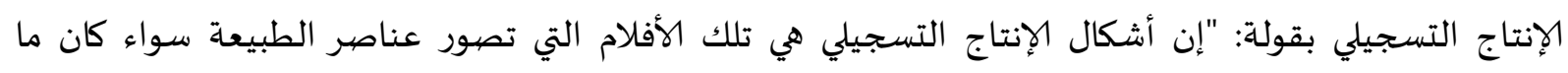

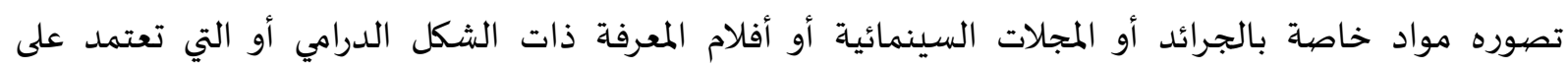

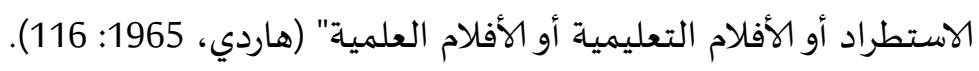

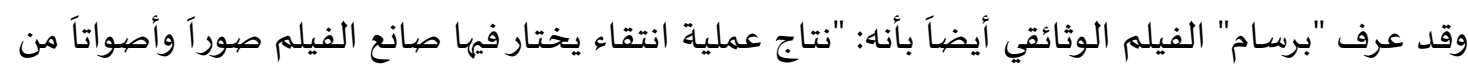

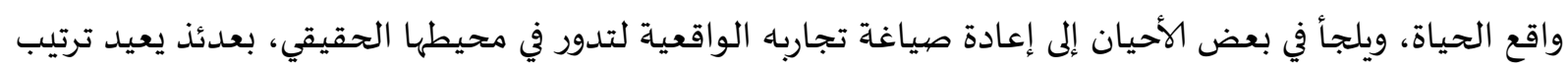

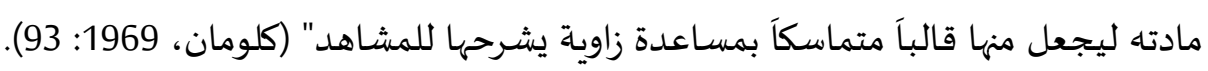

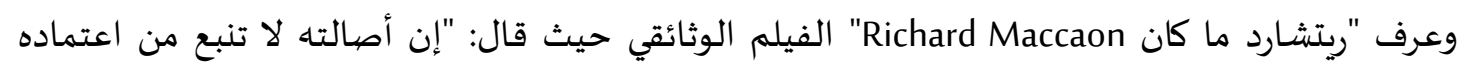

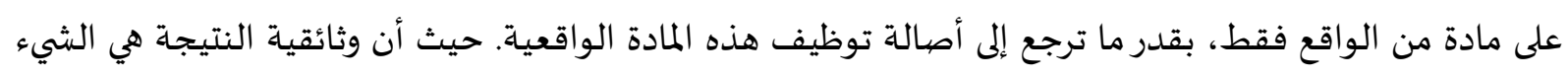

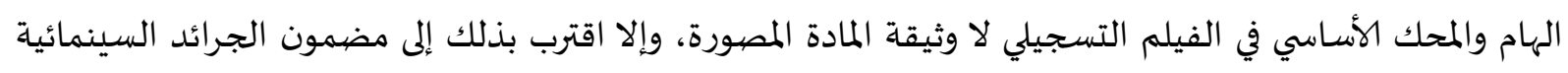
التي تقدم واقعية، حقيقية موثوقاً بها. ولكنها لا تتجاوز الناحية الإخبارية (Barsamm, 1974, p. 2).

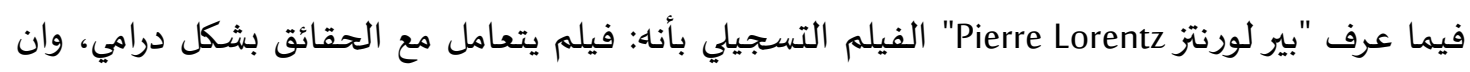

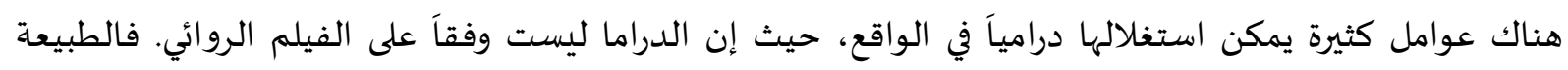

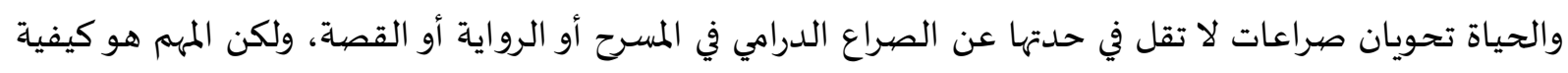

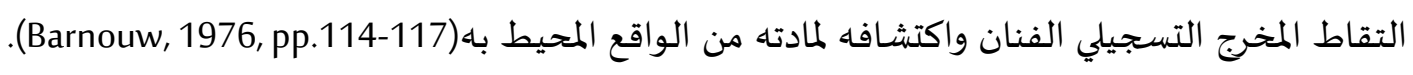

\section{خصيائص البرامج الوثائقية:}

هناك مجموعة من الخصائص التي يتميز بها البرنامج الوثائقي، وهي على النحو الآتي: (قاقيش، 2015: 47-48)

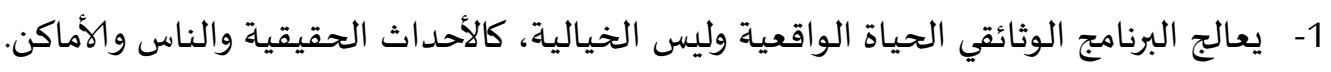

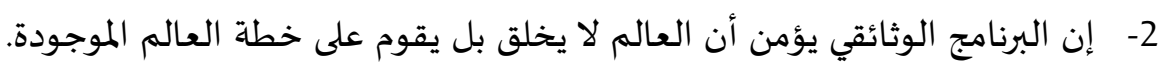

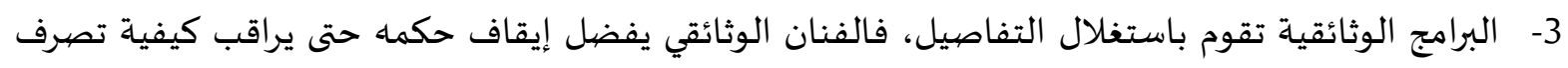
الشخص في الواقع. 
4- البرامج الوثائقي يتميز بالتوثيق، فهو أكبر مصدر كامن للجدول في الفيلم الوثائقي.

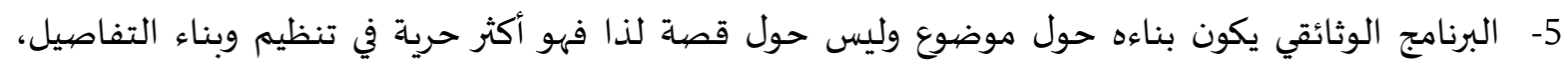

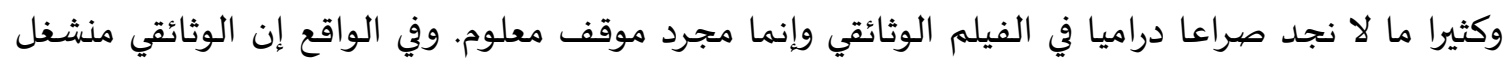

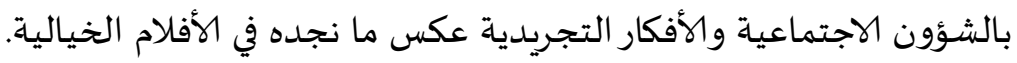

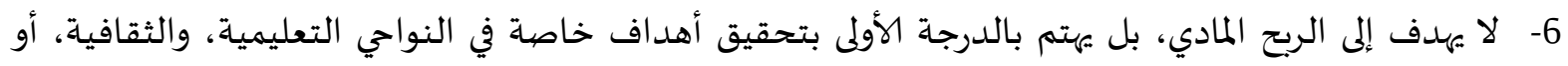

$$
\text { حفظ التراث والتاريخ. }
$$

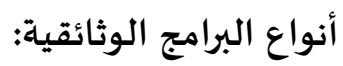

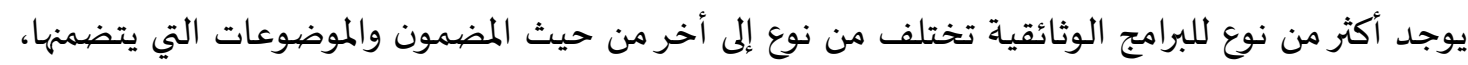

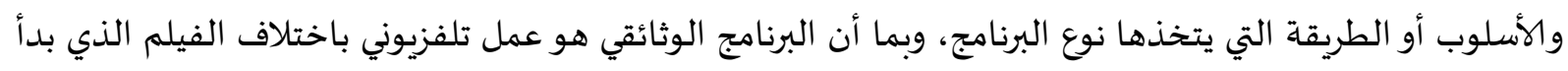

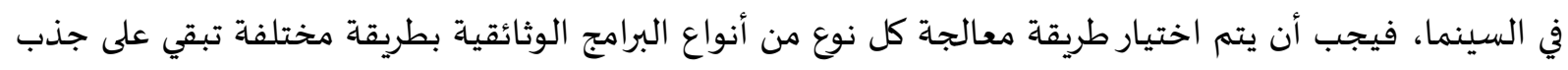

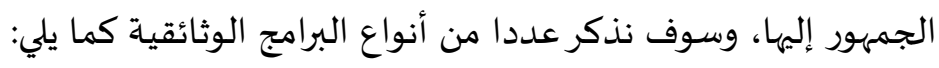

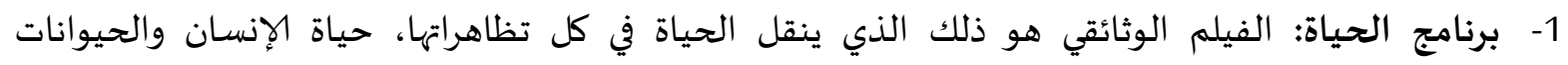

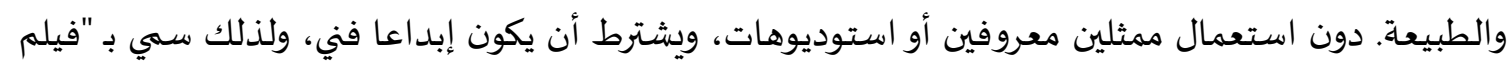

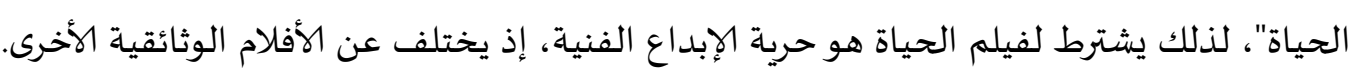

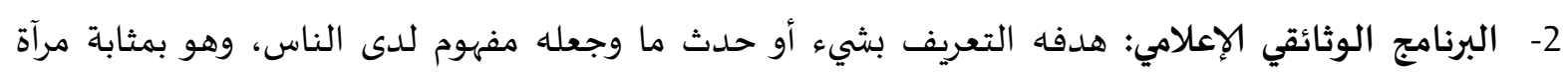

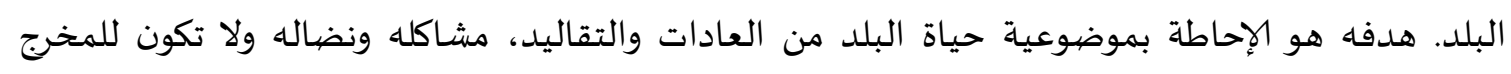

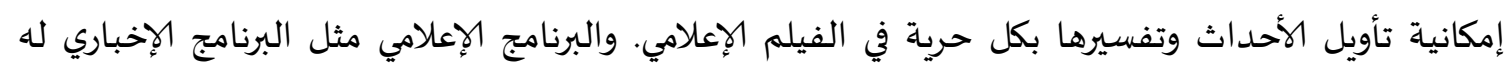

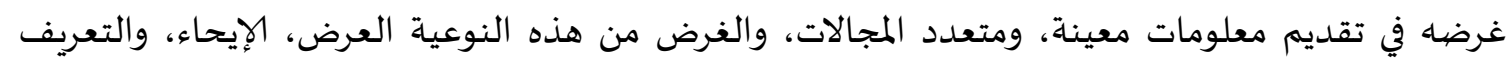

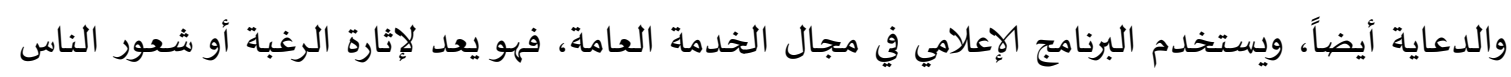

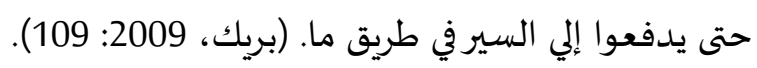

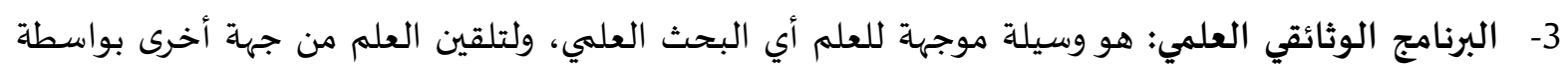

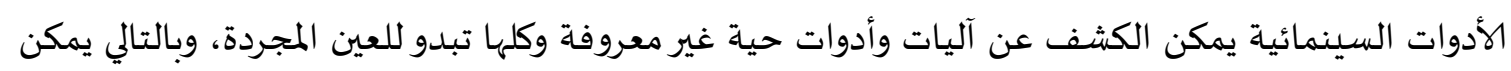

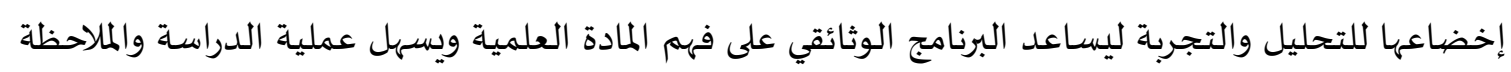

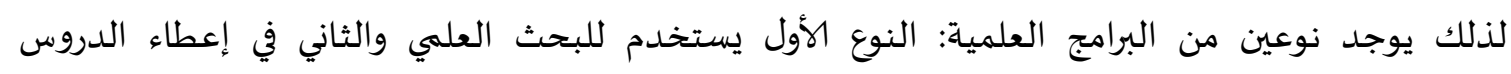

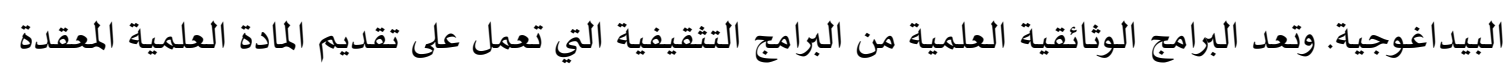

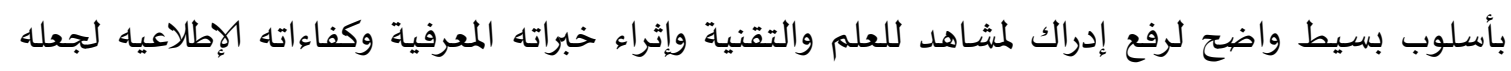

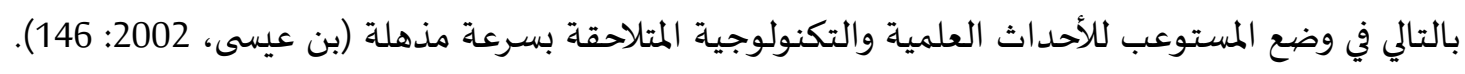

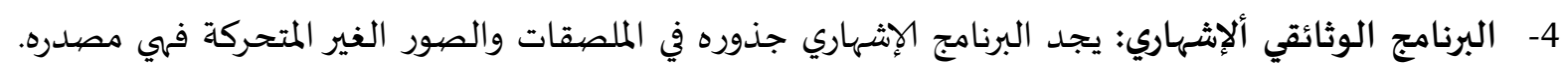

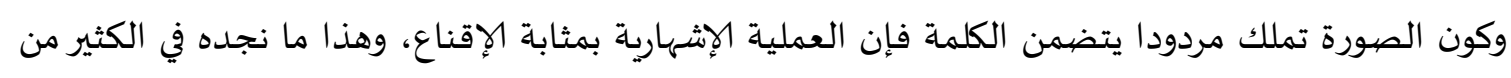

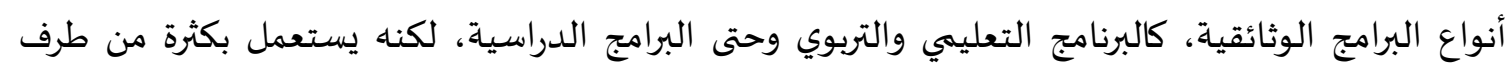

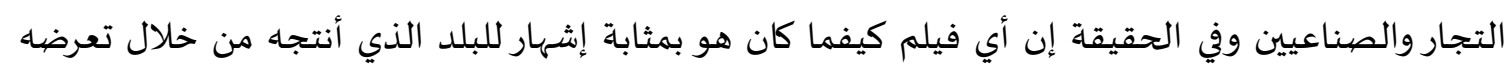

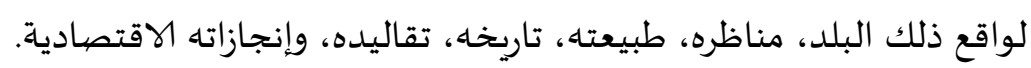

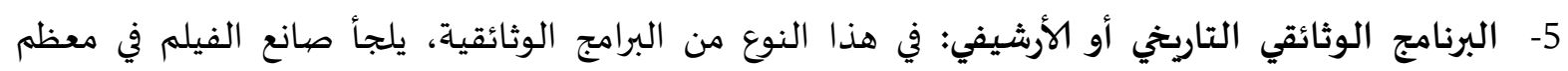

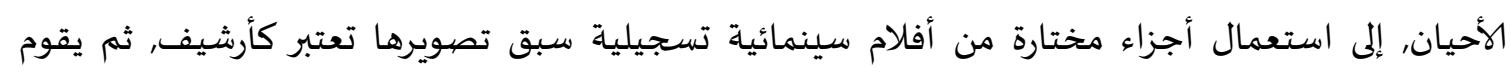


بإعادة وضع هذه الأجزاء المصورة من قبل - في ترتيب وتوقيت محددين تبعا لموضوع الفيلم أو الفكرة

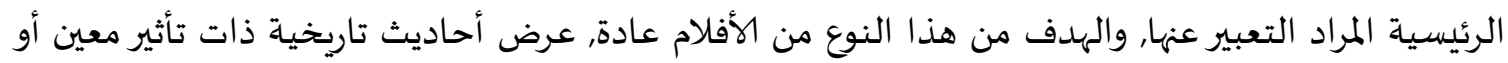

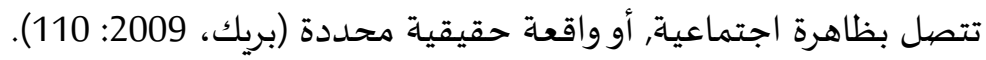

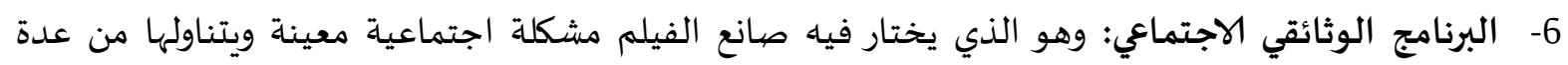

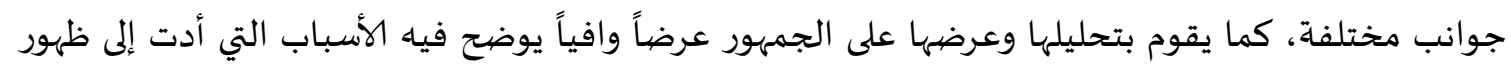

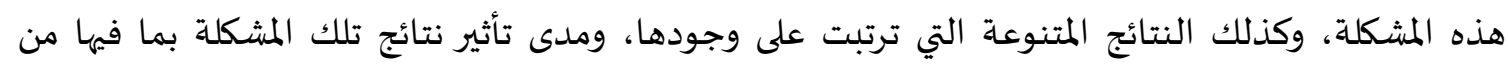
سلبيات وإيجابيات على المجتمع ككل. (سعد الدين، 2009: 15)

فضائيات وثائقية في السماء العربية

قناة الجزيرة الوثائقية:

تحت شعار وراء كل صورة ... حكاية، انطلقت قناة الجزيرة الوثائقية والتي تتبع لقناة الجزيرة الإخبارية

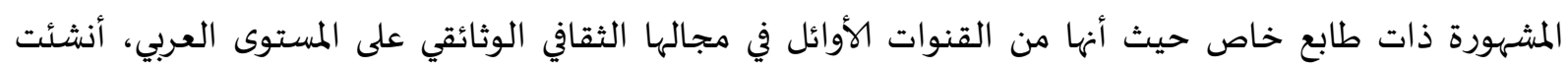

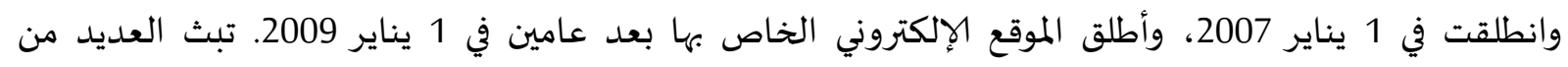

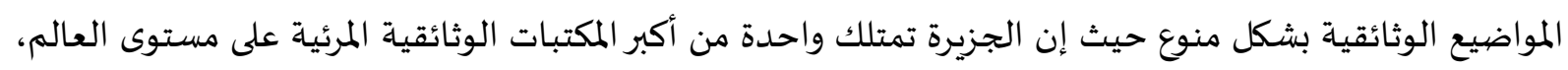

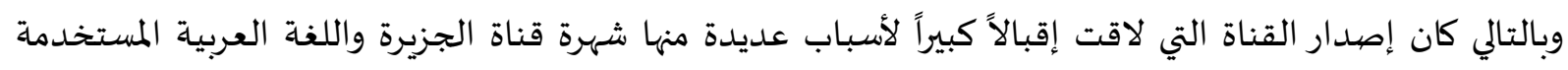

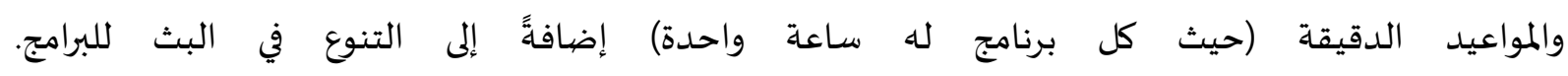
(/https://ar.wikipedia.org/wiki) جاءت فكرة هذه القناة من كون قناة الجزيرة تمتلك واحدة من أكبر المكتبات الوثائقية المرئية على مستوى

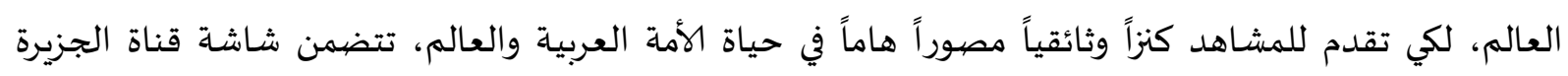

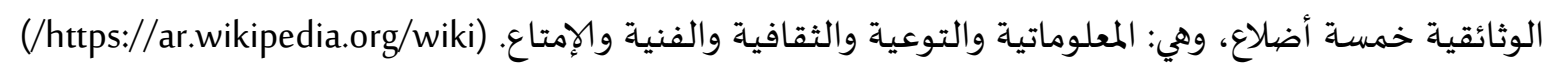

\section{ناشيونال جيوغرافيك أبو ظبي:}

أطلقت قناة ناشيونال جيوغرافيك أبو ظبي في شهر يوليو من عام 2009، وتدعو القناة غير المُشَفَّرَة مشاهديها في الشرق الأوسط إلى إعادة التفكير والنظر في الطريقة التي يشاهدون بها التهاف التلفاز -والطريقة التي ينظرون بها

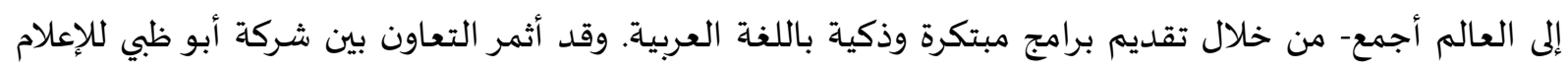

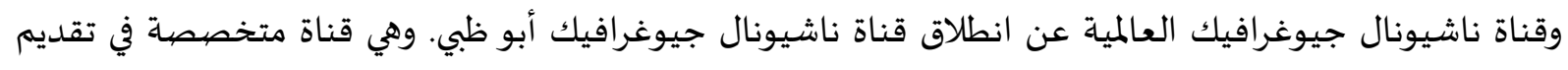

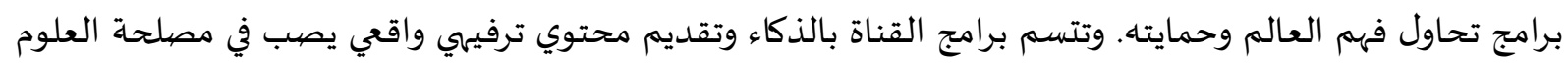
الشائعة والتكنولوجيا وعلم الآثار والألغاز الطبيعية والتاريخ الطبيعي.

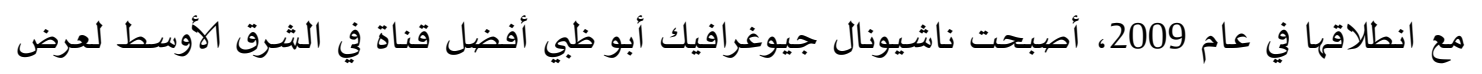

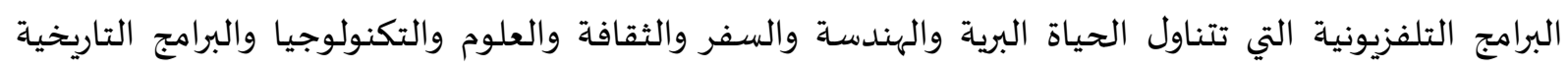
والتحقيقات. (https://ar.wikipedia.org)

ثانياً- الدراسـات السابقة وهنا عرض موجزلما قام باه الباحثون الآخرون في نفس مجال البحث: 
دراسة خديجة بريك (2017)، بعنوان خصوصية البرامج الوثائقية في قناة الجزيرة الإخبارية "دراسة تحليلية في

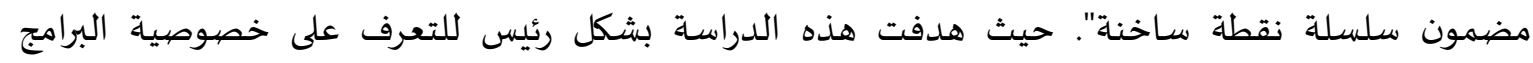

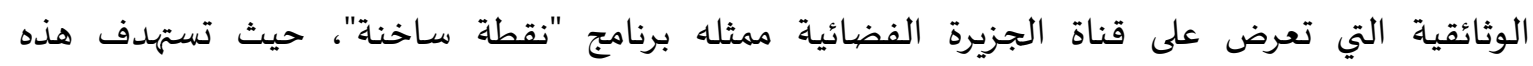

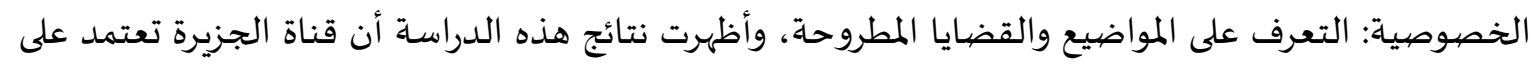

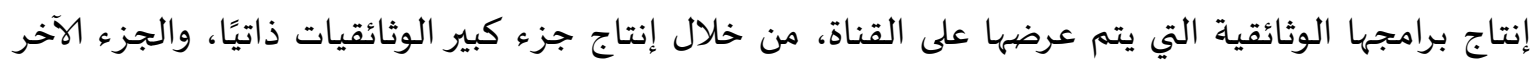

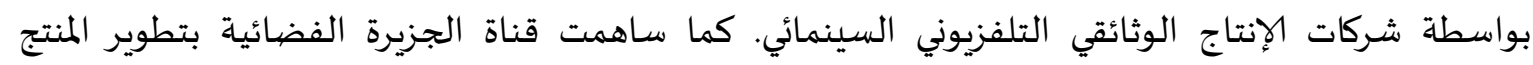

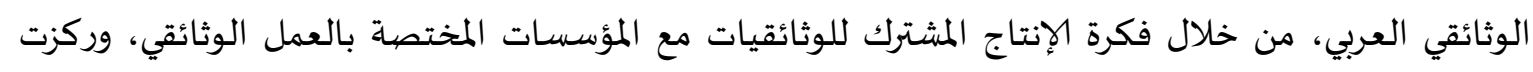

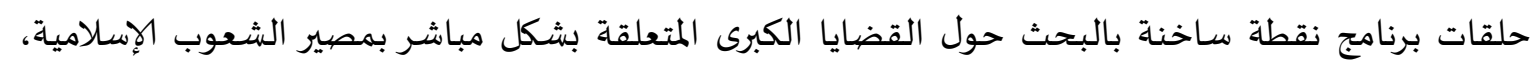

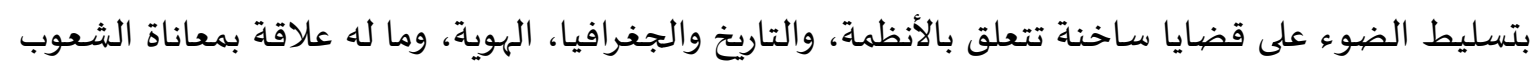
الإسلامية من حروب واحتلال واستعمار وتحرر وثورات. دراسة عدي قاقيش (2015)، استخدام طلبة الجامعات الأردنية للبرامج الوثائقية والإشباعات المتحققة منها،

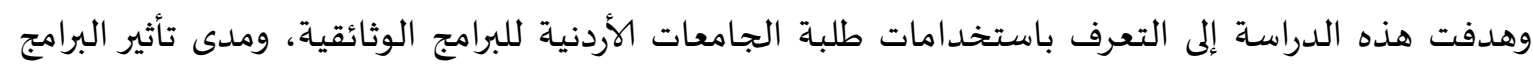

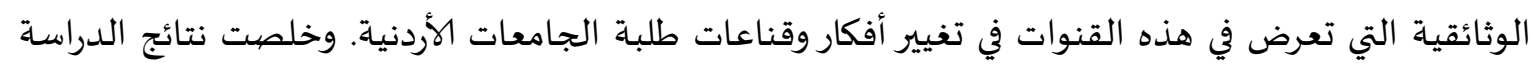

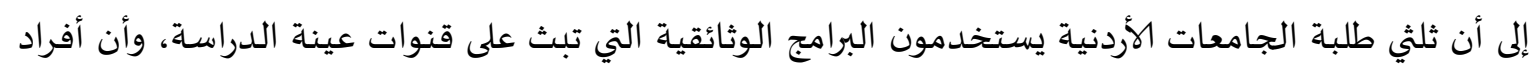

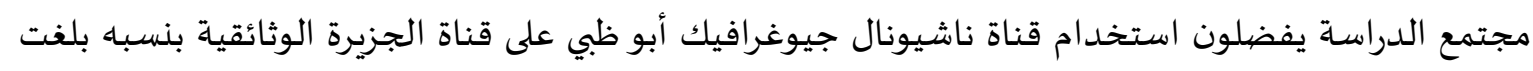

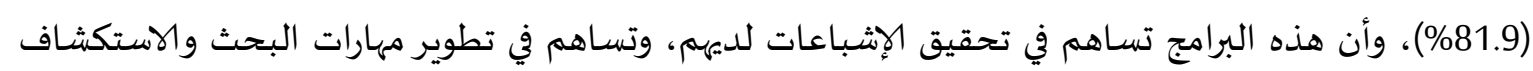

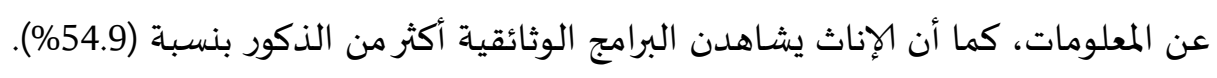

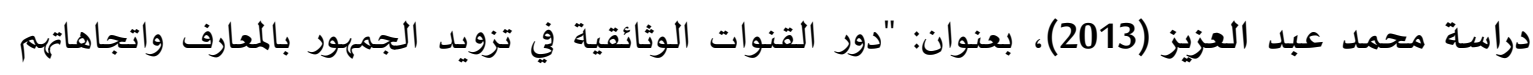

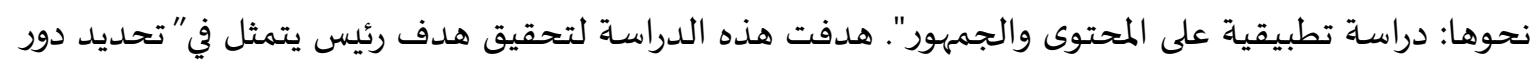

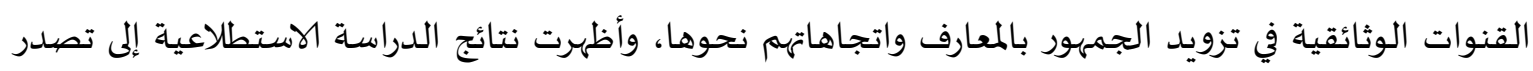

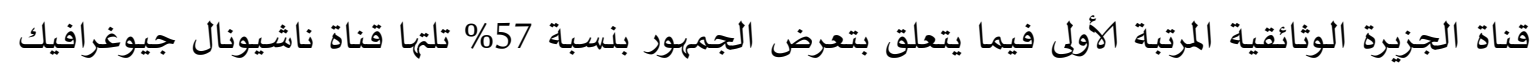

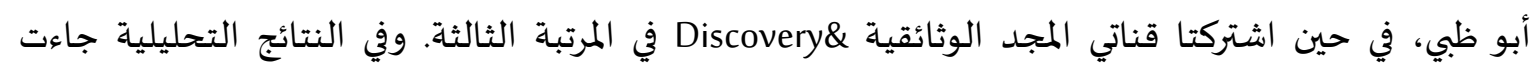

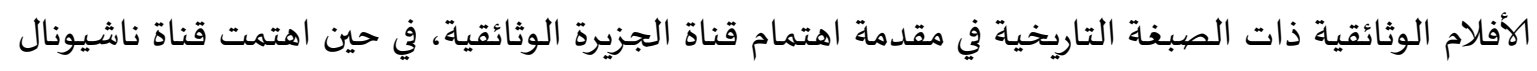

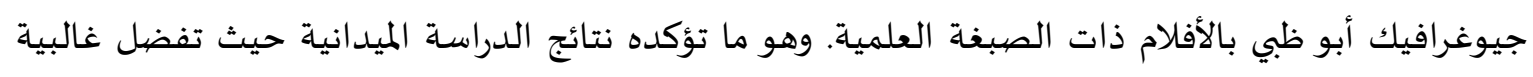

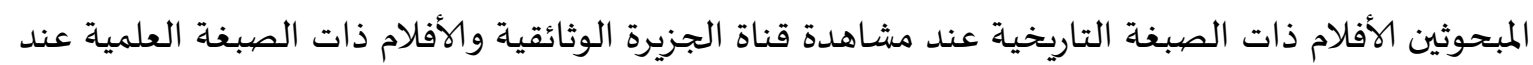

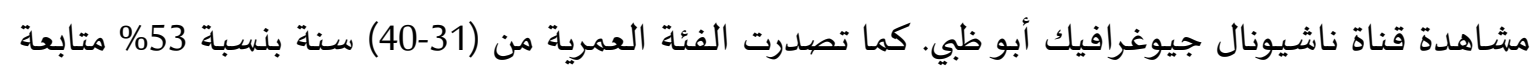

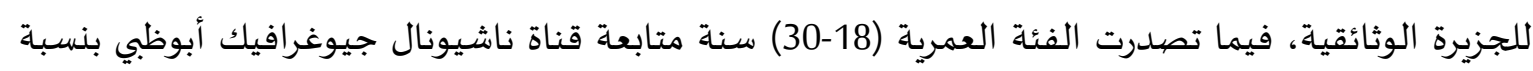

63\% من حملة المؤهلات الجامعية.

دراسة نهلة عبد الرزاق عبد الخالق رشيد (2011)، بعنوان: "دراسة تحليل مضمون للأفلام التسجيلية

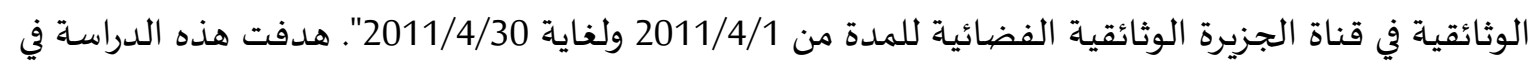

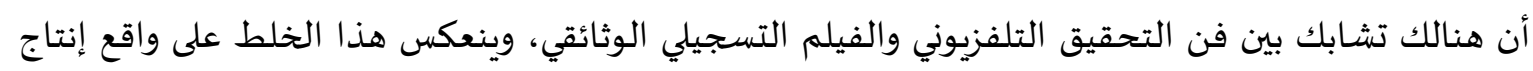

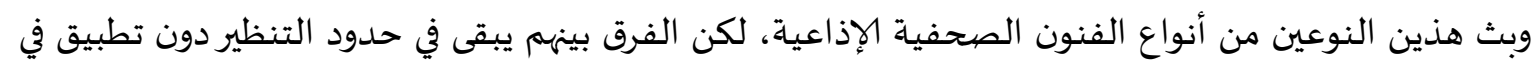

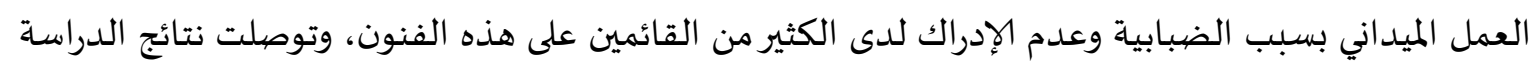

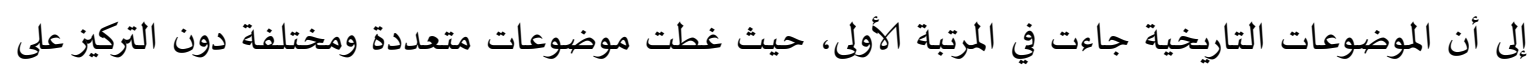

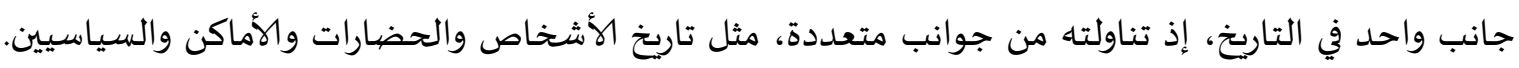


كما أن معظم البرامج والأفلام الوثائقية هي من إنتاج قناة الجزبرة الوثائقية وهذا يوضح إمكانياتها وانتشارها الواسع في مختلف أنحاء العالم. دراسة خديجة بريك (2009)، بعنوان: "جمهور البرامج الوثائقية في القنوات الفضائية دراسة في الاستخدامات

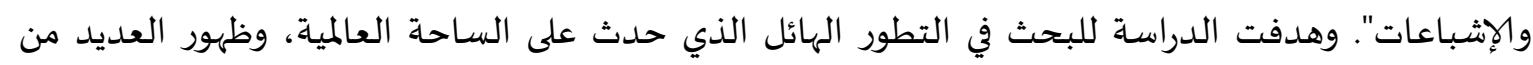

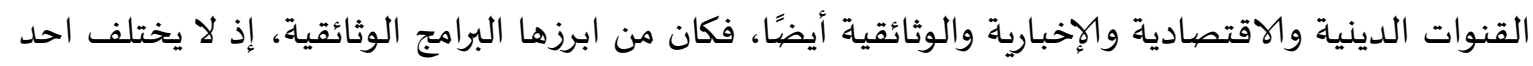

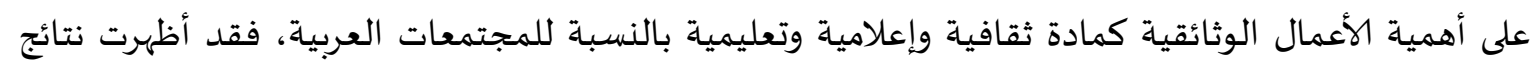

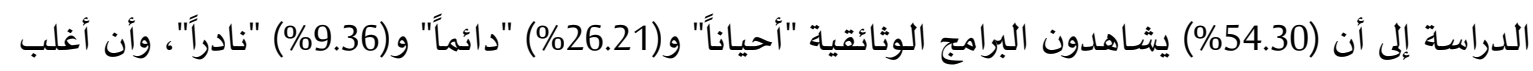

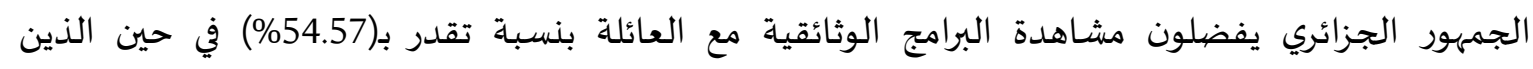

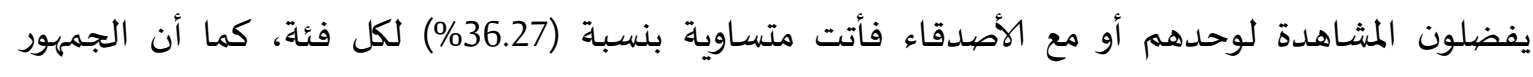

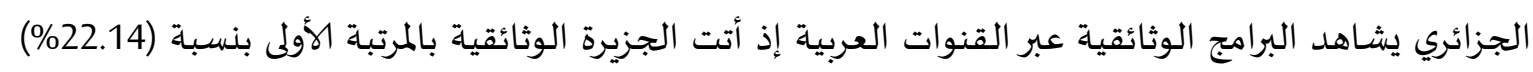

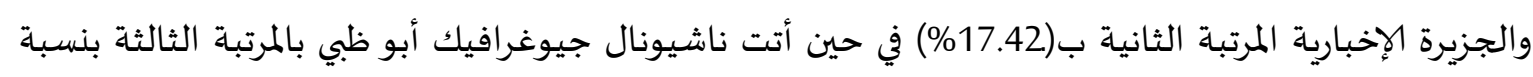

16.42\% وقناة العربية رابعاً بنسبة (13.16\%).

دراسة لويس مورينو Moreno, Luis (2014)، بعنوان "البحث وسط الأنقاض: الفيلم الوثائقي الإسباني

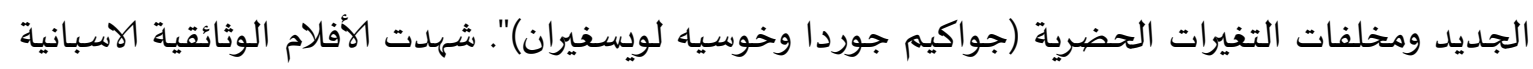

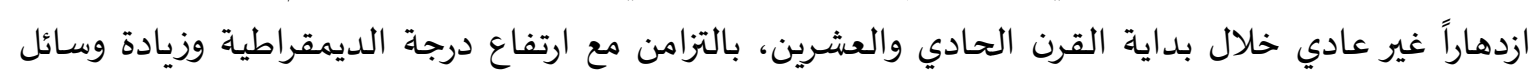

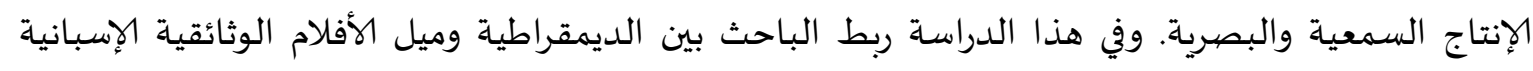

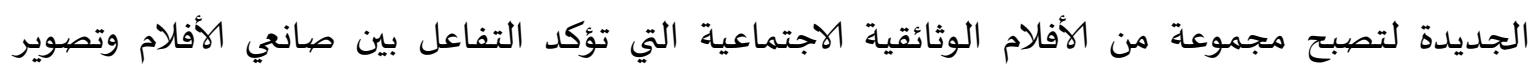

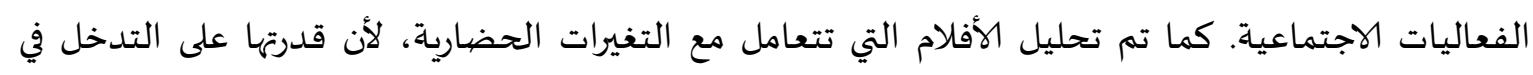

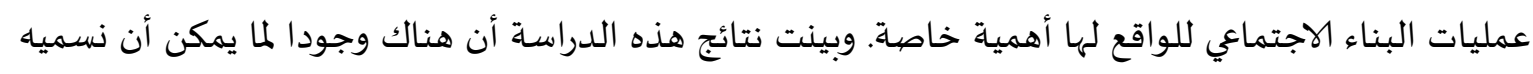

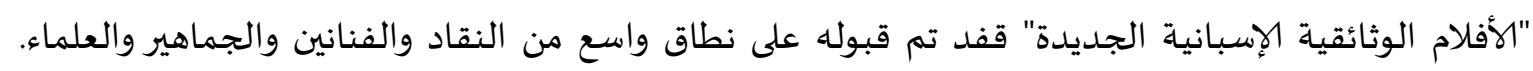

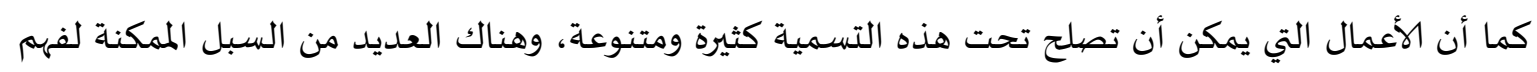
ما هو 'الجديد' عنهم. دراسة Fitch, Wroblewski \& Piemyat (1997)، بعنوان: تأثيرات التلفزيون الوثائقي والقصصي في بنية

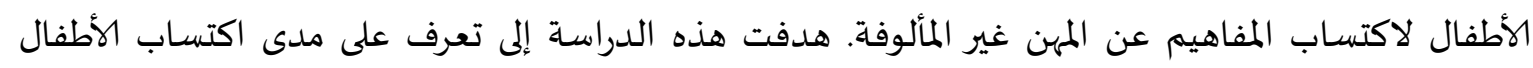

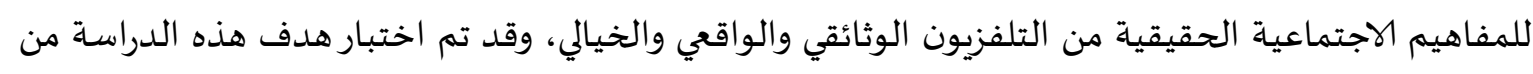

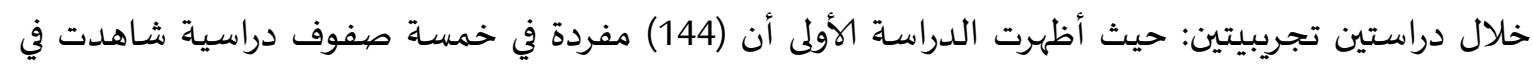

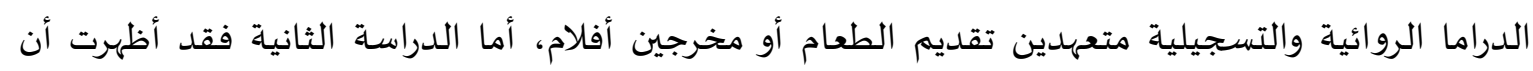

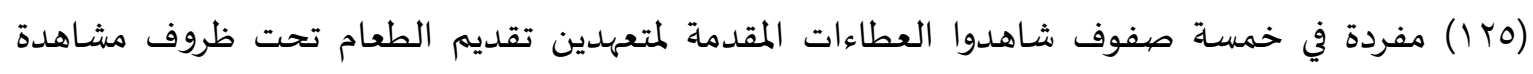

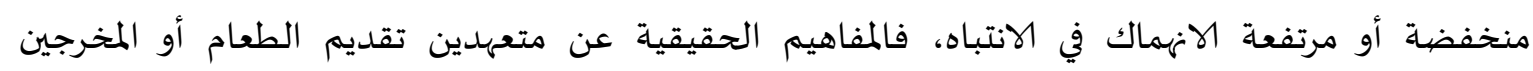

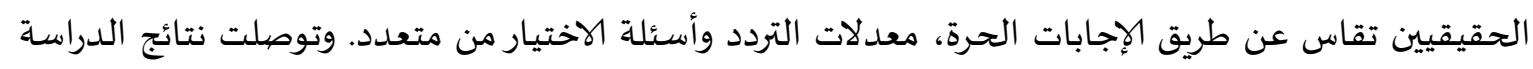

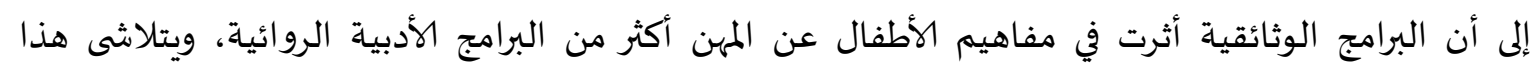
الاختلاف بسهولة بعد مرورشهر، ولا يختلف مستوى الانهماك في المشاهدة بين الفيديو الوثائقي والروائي. 


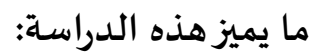

إن ما يميز هذه الدراسـة عن غيرها من الدراسات السابقة التي تتحدث عن موضوع البرامج الوثائقية في أنها

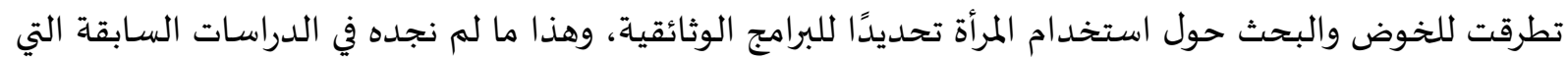

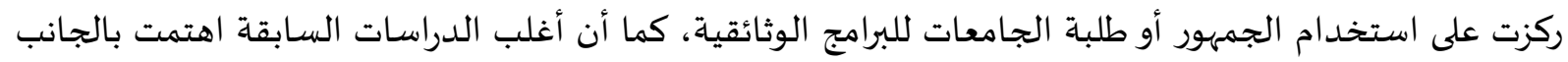

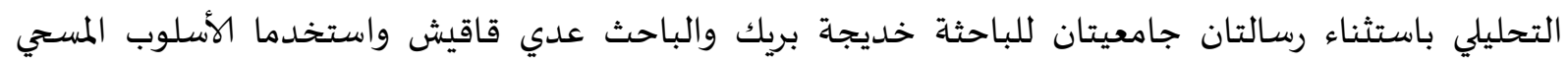

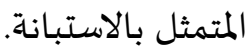

3- منهجية الدراسـة وإجراءاتها

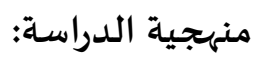

اعتمد هذا البحث على استخدام المنهج الوصفي التحليلي باستخدام اداة المسح بالعينة، والتي تعد من

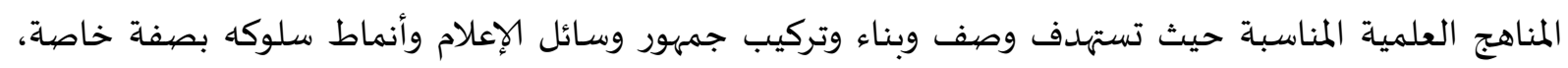
حيث ترتكز على وصف طبيعة وسمات وخصائص مجتمع معين أو موقف أو جماعة أو فرد معين، وتكرارات حدوث واثل

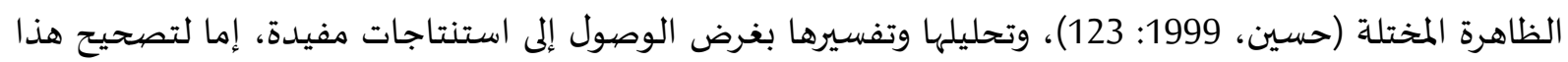

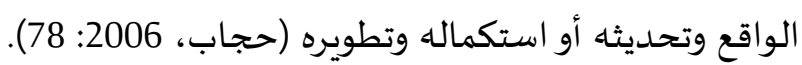
ولكي يتم الوصول إلى هذه النتائج بشكل دقيق ويمثل جوانب الأداء لهذهذه الدهاء الدراسة تم اعتماد استبيان

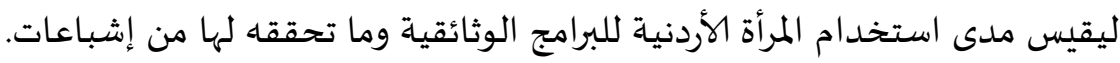

مجتمع الدراسـة تكون مجتمع الدراسة من المرأة الأردنية في محافظات العاصمة عمّان والزرقاء وإبربد، والتي تشهد كثافة سكانية عالية ويقطها أكثر من ثلثي سكان المملكة.

وصف عينة الدراسة:

تكونت عينة الدراسة من 300 امرأة أردنية من المحافظات الأردنية الثلاث عمّان والزرقاء وإربد ذات الكثافة السكانية العالية مقارنة بباقي محافظات المملكة، وبواقع 100 استبيان لكل محافظة. وتم اختيار العينة بطريقة عشوائية البسيطة لإعطاء كل وحدات العينة ضمن مجتمع الدراسة فرصاتة متساوية لاحتمال تمثيلها ضمن عينة

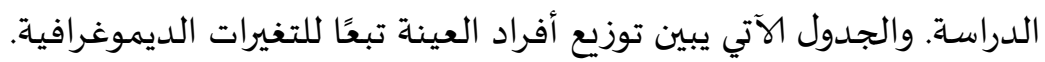
وتاليًا نبين نسبة المشاهدة بحسب التغيرات الديموغرافية بالنسبة لعينة الدراسة.

1. توزيع نسبة المشاهدة لعينة الدراسة حسب السن 


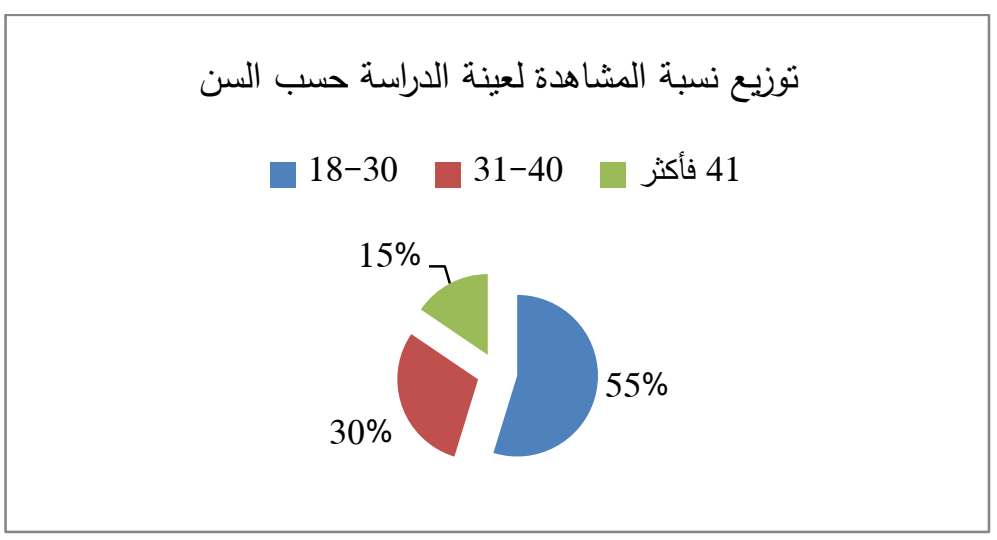

الشكل رقم (1) توزيع نسبة مشاهدة العينة بحسب السن

يشير الشكل رقم (1): إن أبرز تكرار للمشاهدة لمتغير السن كان للفئة العمرية (18-30) حيث بلغ عدد المدئ اللواتي يشاهدن البرامج الوثائقية من هذه الفئة العمرية (127) تكرارًا بنسبة مئوية بلغت اندئ (54.7)، تلاها الفئة الفئة

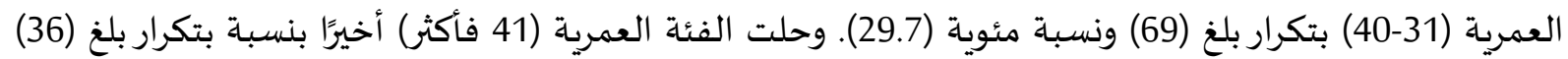
وبنسبة مئوية بلغت (15.5). وهذا ما يشير إلى أن للفئة العمرية دور في متابعة البرامج الوثائقية بالنسبة للمرأة الأردنية حيث أشارت

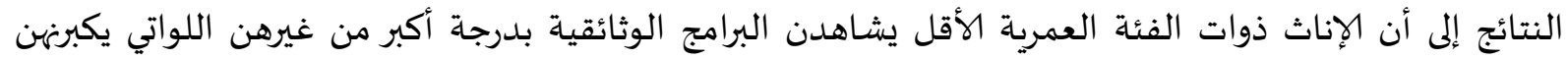
عمرًا. 2. توزيع نسبة المشاهدة لعينة الدراسة حسب المستوى العلمي

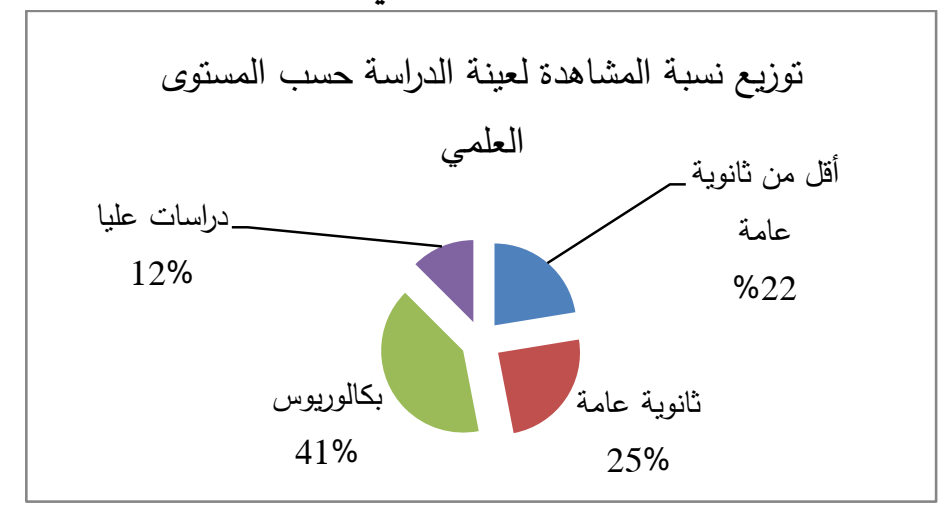

الشكل رقم (2) توزيع نسبة مشاهدة العينة بحسب المستوى العلمي

يشير الشكل رقم (2) إن أبرز تكرار للمشاهدة لمتغير المستوى التعليمي كان للمستوى التعليمي (بكالوريوس)

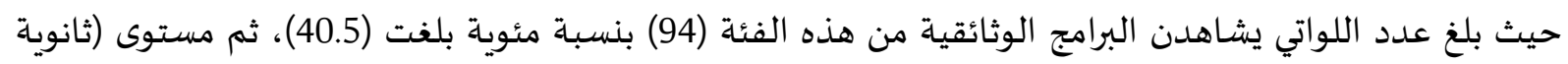
عامة) بتكرار بلغ (52) وبنسبة مئوية (24.5)، وحل أخيرًا مستوى (دراسات عليا) بتكرار بلغ (29) ونسبة مئوية (12.5).

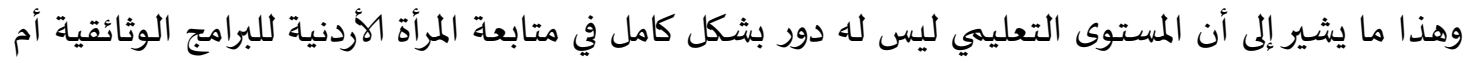

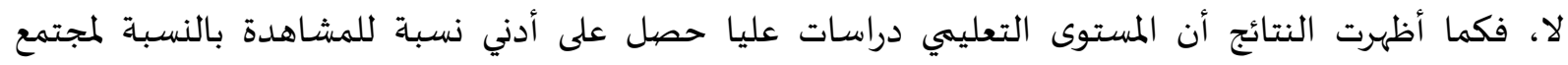

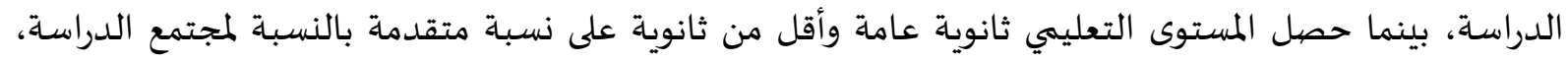
وهذا ما يدل أن المرأة الأردنية تتابع البرامج الوثائقية دون النظر للمستوى التهائه التعليهي لها. 


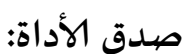

وقام الباحثان بالتأكد من صدل الاستبيان من خلال اختبار الصدق، حيث عرض الاستبيان على مجموعاه

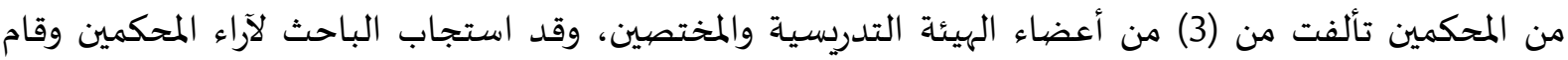
بإجراء ما يلزم من حذف وتعديل في ضوء المناء المقترحات المقدمة.

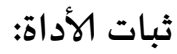
بغرض التأكد من ثبات أداة الدراسة (الاستبانة) تم تطبيق معادلة كرونباخ ألفا على جميع مجالات

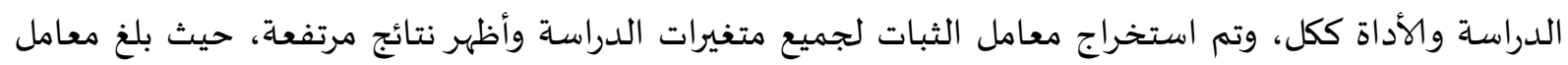
الثبات لكل فقرات الأداة (ألفا=0.870)

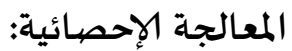

لاختبار فرضيات الدراسة تم استخدام المعالجات الإحصائية التالية من خلال برنامج الرزم الإحصائية

1 1. التكرارات والنسب المئوية لإجابات أفراد عينة الدراسة.

2. المتوسطات الحسابية الترتيبية والانحرافات المعيارية.

3. مربع كاي (chi-spuare)، للكشف عن الفروق في إجابات أفراد العينة على متغيرات الدراسـة.

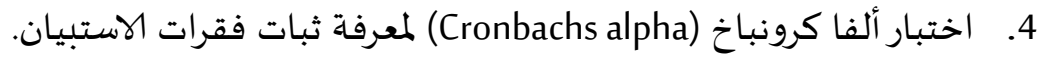

4- عرض النتائج ومناقشتها. • المحور الأول: طبيعة مشاهدة البرامج الوثائقية لدى المرأة الأردنية؟

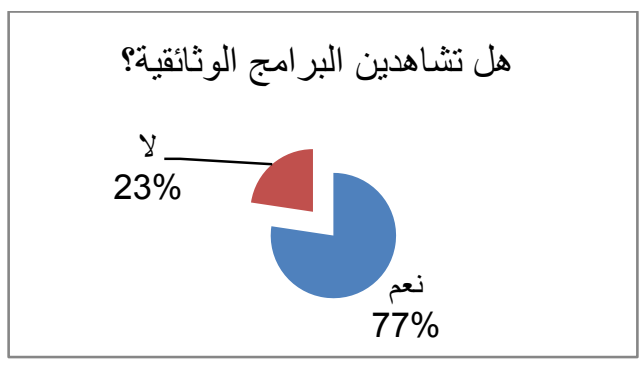

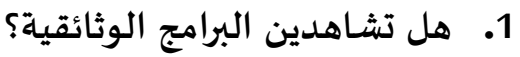

\section{الشكل رقم (3) نسبة مشاهدة البرامج الوثائقية}

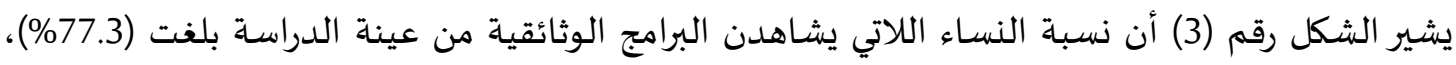

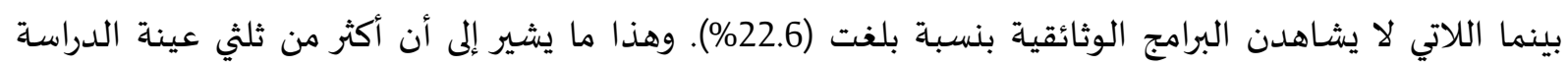

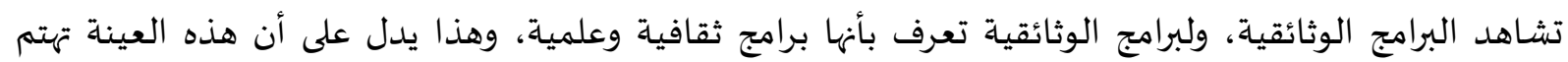
بالمعرفة والثقافة.

2. - عدد مشاهدات البرامج الوثائقية خلال الأسبوع؟ 


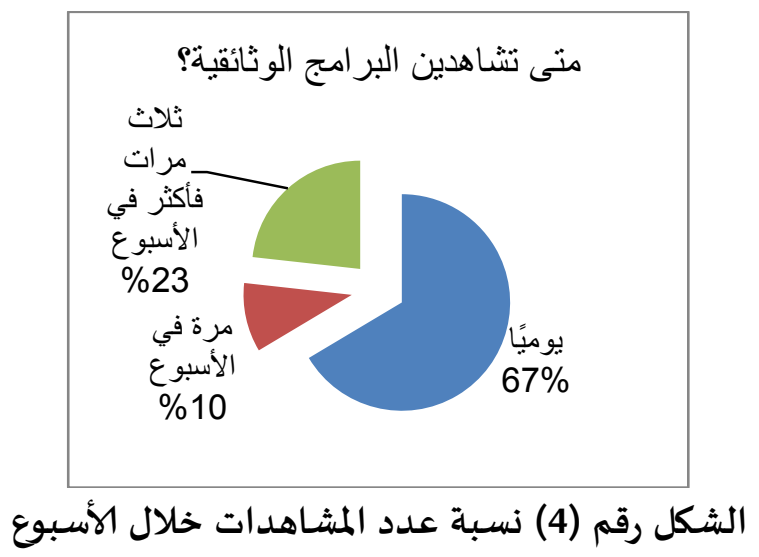

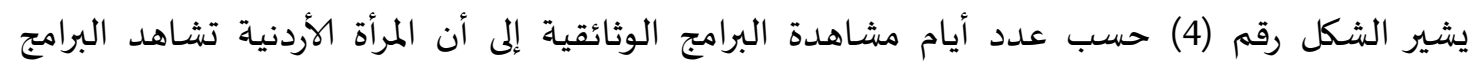

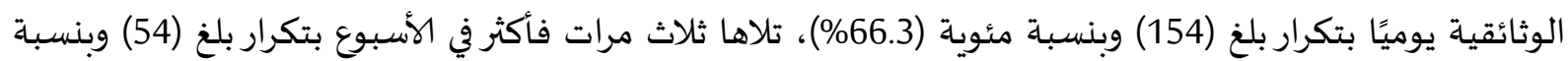

هذه النتيجة تشير إلى أغلب عينة الدراسة تتابع البرامج الوثائقية بشكل يومي، وهذا ما يدل على كثافة المتابعة واهتمام عينة الدراسة لمتابعة البرامج الوثائقية.

3. ما الأوقات المناسبة التي تشاهدين فهها البرامج الوثائقية؟

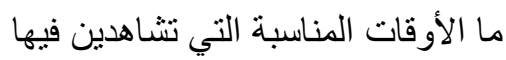

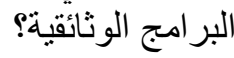

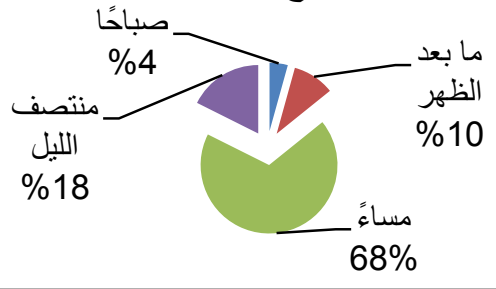

الشكل رقم (5) أوقات مشاهدة البرامج الوثائقية

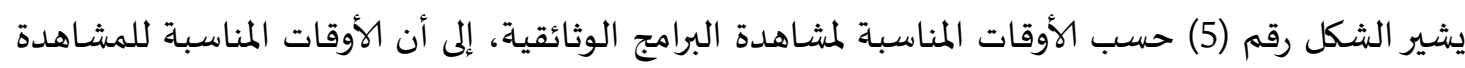

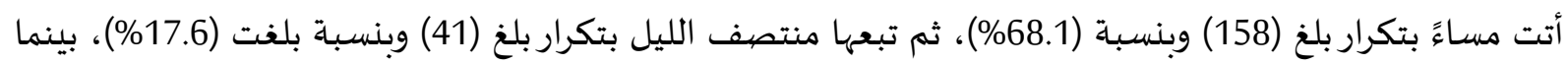

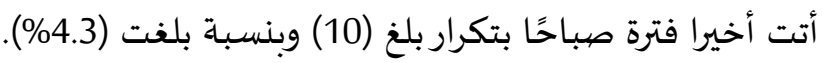

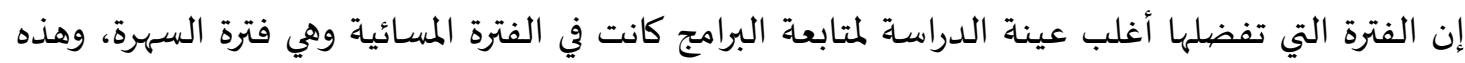

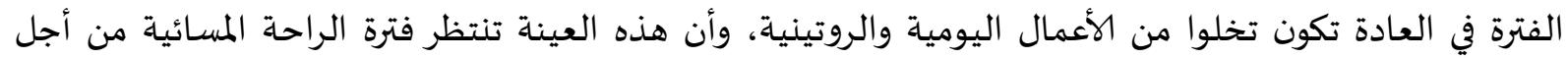

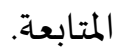

4. ما طبيعة ومضمون البرامج الوثائقية التي تفضلين مشاهدتها؟ 


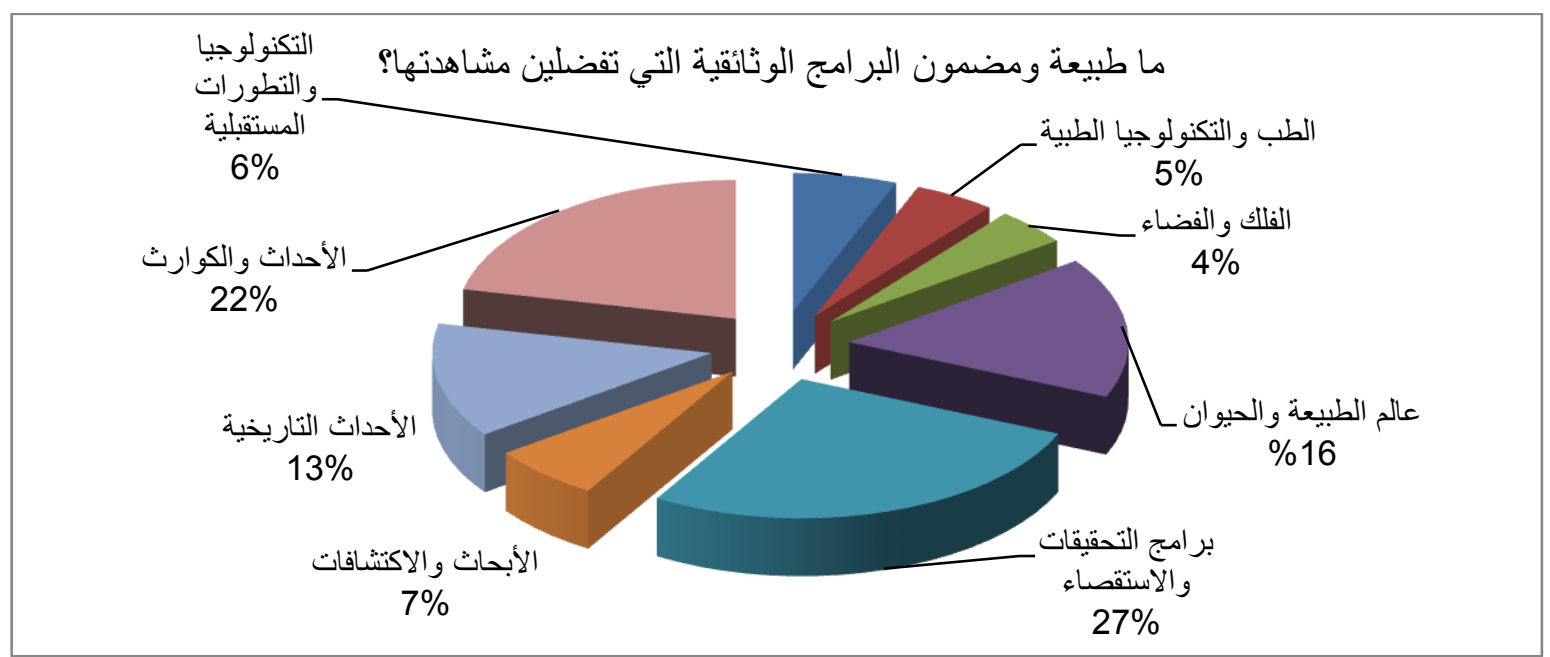

الشكل رقم (6) طبيعة ومضمون البرامج الوثائقية المفضلة

يشير الشكل رقم (6) حسب طبيعة ومضمون البرامج الوثائقية التي تفضل عينة الدراسة مشاهدتها إلى أن أن طبيعة ومضمون البرامج التي تفضلها عينة الدراسة هي برامج التحقيقات وبرامج الاستقصاء بتكرار بلغ (63) وبنسبة التبات

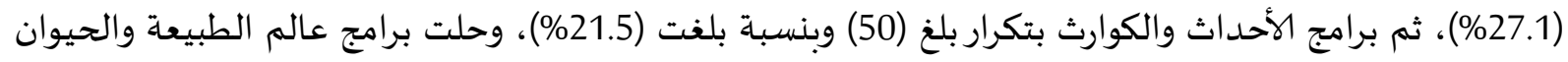
في المرتبة الثالثة بتكرار (38) وبنسبة (16.3\%)، فيما أتت برامج الفلك والفضاء بالمرتبة الأخيرة بتكرار بلغ (10) وبنسبة (4.3\%).

تشير النتائج أن عينة الدراسة تفضل متابعة البرامج التي من شأنها كشف الحقائق والأحداث التي تقف

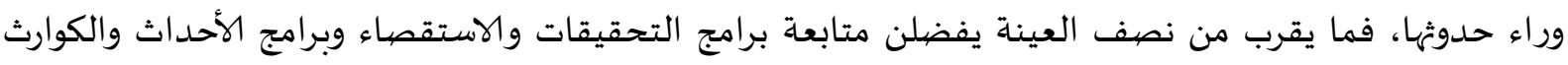

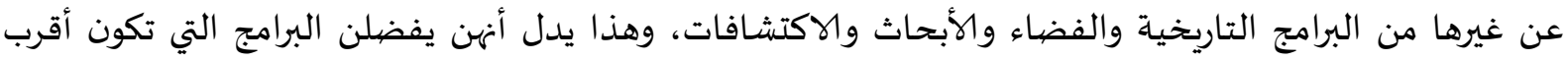

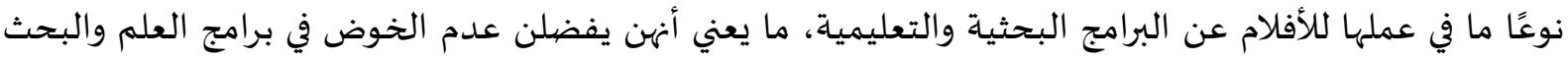
أثناء فترة المتابعة بشكل كبير.

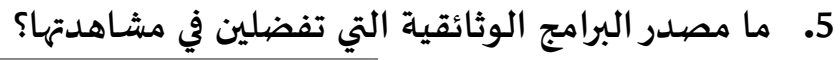

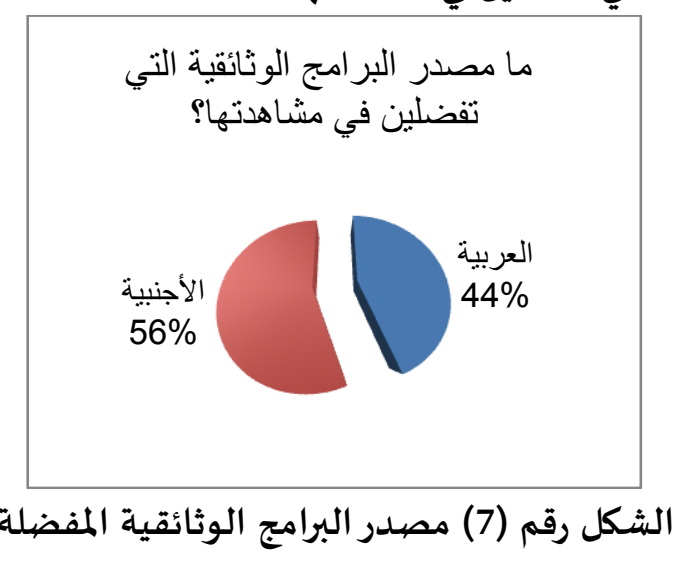

يشير الشكل رقم (7) حسب مصدر البرامج الوثائقية التي تفضلها عينة الدراسة إلى أن مصدر البرامج

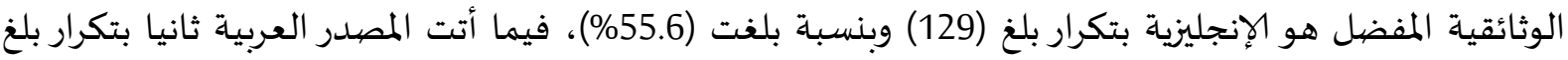
(103) وبنسبة بلغت (44.3\%). تشير النتائج أن غالبية المبحوثات بفضل البرامج الوثائقية ذات المصددر الأجنبي على المصدر العربي، وهذه

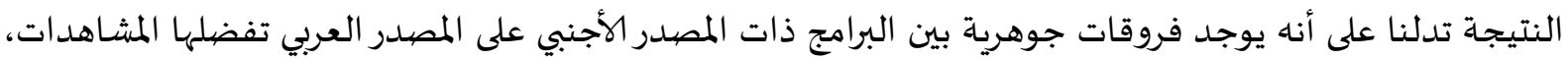
وهذا يؤشر على وجود مشكلة أو أسباب محددة تساهم في تفضيلهن للبرامج الاجنبية على العربية، وكانت أشارت 
دراسة (قاقيش 2015) على أن طلبة الجامعات الأردنية يفضلون متابعة البرامج الوثائقية الأجنبية على العربية نظرًا

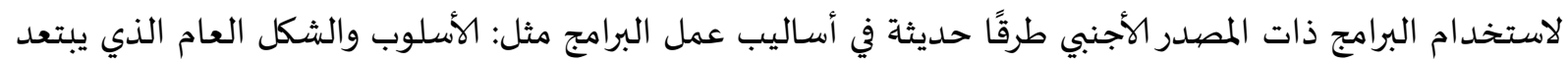

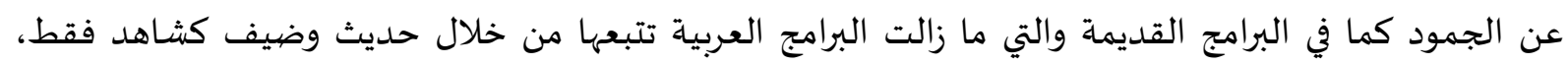

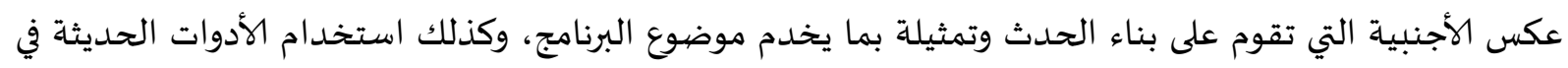
التصوير والمونتاج وما شابهها من أمور تقنية.

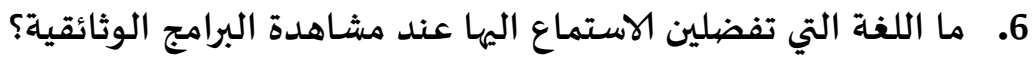

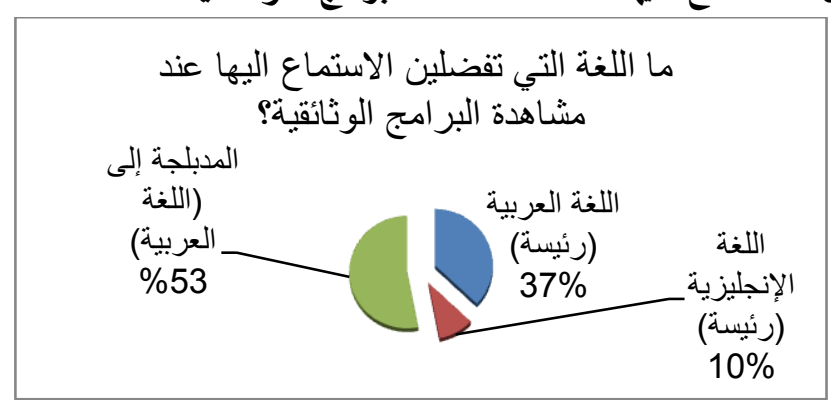

الشكل رقم (8) لغة البرامج الوثائقية المفضلة

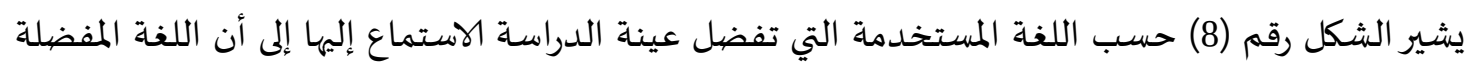

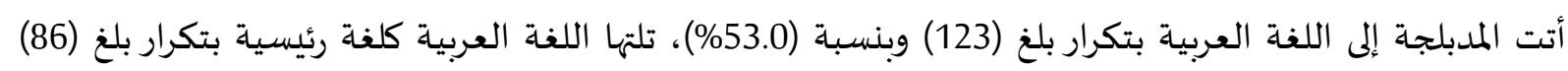

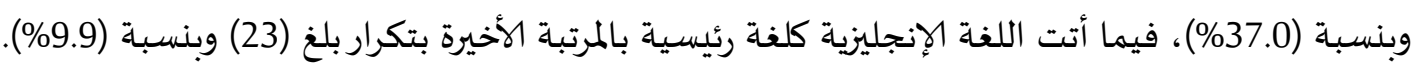

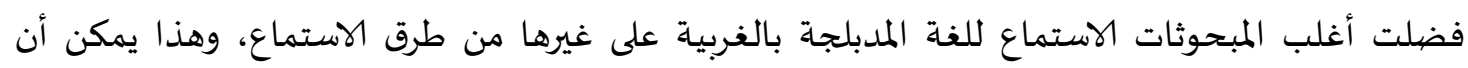

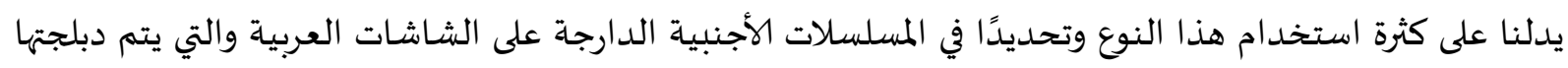
للغة العربية الدارجة.

7.

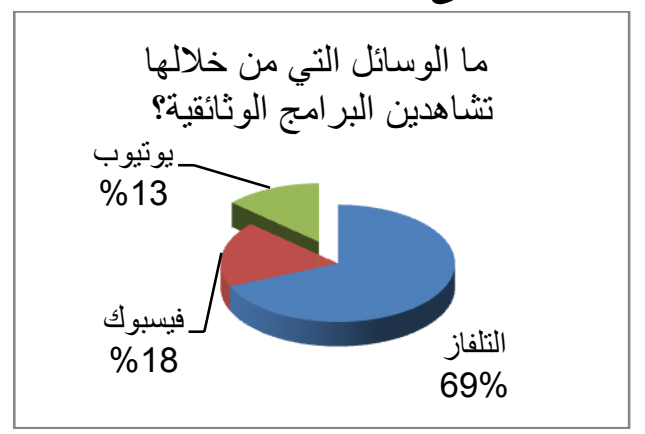

الشكل رقم (9) الوسائل التي تستخدم لمشاهدة البرامج الوثائقية

يشير الشكل رقم (9) حسب الوسائل التي يتم من خلالها مشاهدة البرامج الوثائقية إلى أن الوسيلة

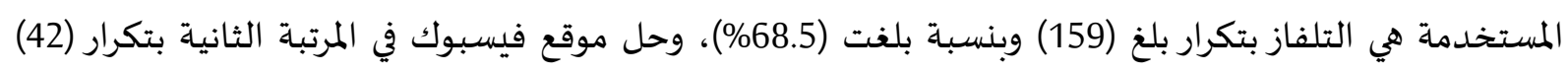

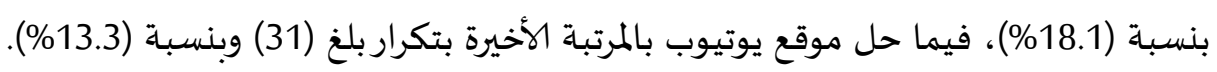

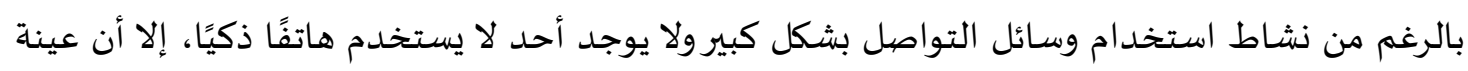

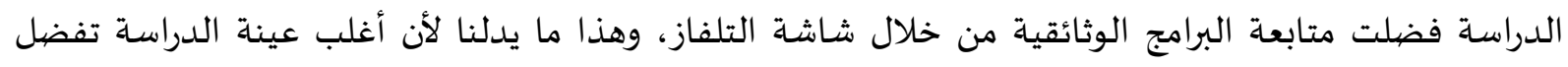

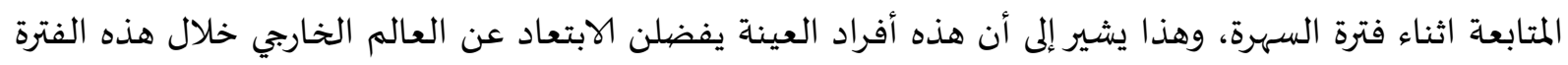
والاكتفاء في المحيط العائلي فقط. 
8

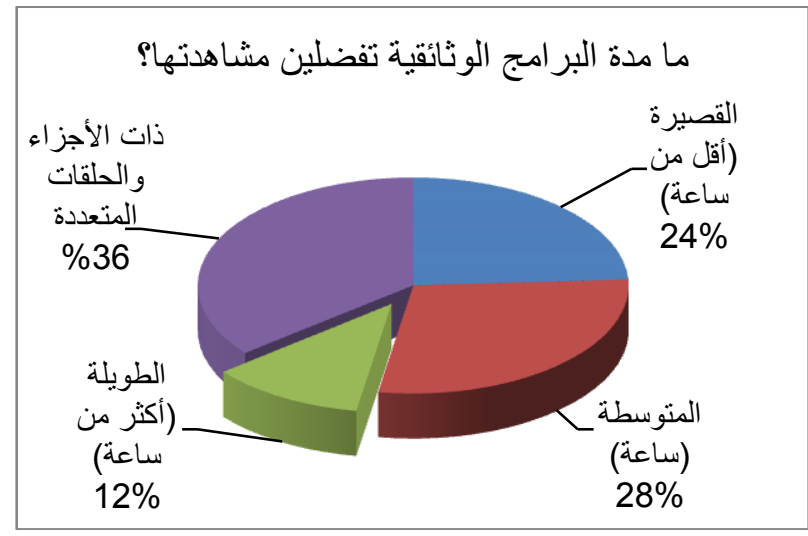

الشكل رقم (10) مدة البرامج الوثائقية المفضلة

يشير الشكل رقم (10) حسب مدة البرامج الوثائقية التي تفضل عينة الدراسة مشاهدتها وكانت مدة البرامج المفضلة ذات الأجزاء والحلقات المتعددة بتكرار (83) وبنسبة بلغت (35.7\%)، تلتها البرامج المتوسطة (ساعة) بتكرار (66) وبنسبة (28.5\%)، فيما حلت البرامج الطويلة (أكثر من ساعة) بتكرار (27) وبنسبة (11.6\%). تشيشر هذه النتيجة وبنسب متفاوتة إلى أن أغلبية العينة تفضل متابعة البرامج التي تكون ضمن سلسلة حلقات متعددة وساعة فأقل، وهذا يدل على تفضيلهن للبرامج ذات التوقيت المعتدل بعيدًا الأوقات الطويلة التي يمكنها أن تساهم في الملل أو تمنع المشاهدات من عدم تكملة الحلقة الطويلة لسبب أو لآخر.

• المحور الثاني: ما الدوافع والإشباعات المتحققة لدى المرأة الأردنية من خلال استخدام البرامج الوثائقية؟

9. ما دوافع متابعتكِ للبرامج الوثائقية؟ مورك

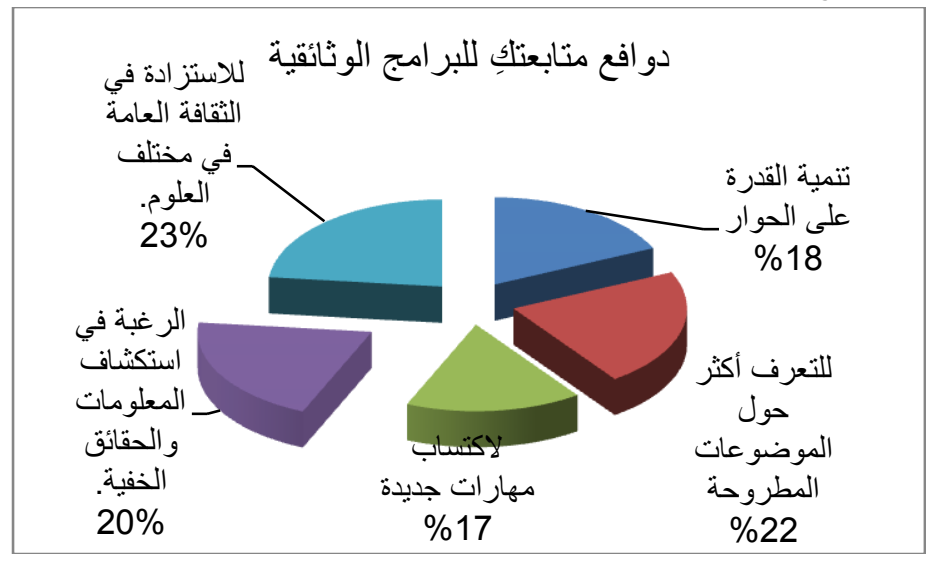

الشكل رقم (11) دوافع متابعة البرامج الوثائقية

يشير الشكل رقم (11) حسب دوافع استخدام البرامج الوثائقية إلى أن دافع الاستخدام للاستزادة في الثقافة

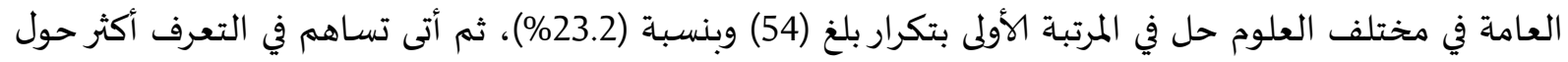
الموضوعات المطروحة بتكرار (51) وبنسبة (21.9\%)، فيما حل أخيرا لاكتساب مهارات جديدة بتكرار (38) وبنسبة بلغت (16.3\%).

تباينت دوافع المشاهدات بين الرغبة في الاستزادة من مختلف العلوم والتعرف على مواضيع جديدة ومعرفة المعلومات الخفية واكتساب مهارات جديدة من هذه البرامج والمساهمة في تنمية القدرة على الحوار في المواضيع 
المختلفة، وهذا يدل على أن المشاهدات يشاهدن هذه البرامج للعديد من الدوافع لاكتساب أنواع مختلفة من المعرفة

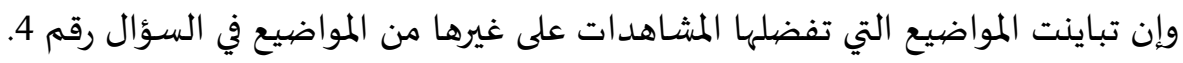
10. ما الإشباعات التي تتحقق لك من خلال متابعتك للبرامج الوثائقية؟

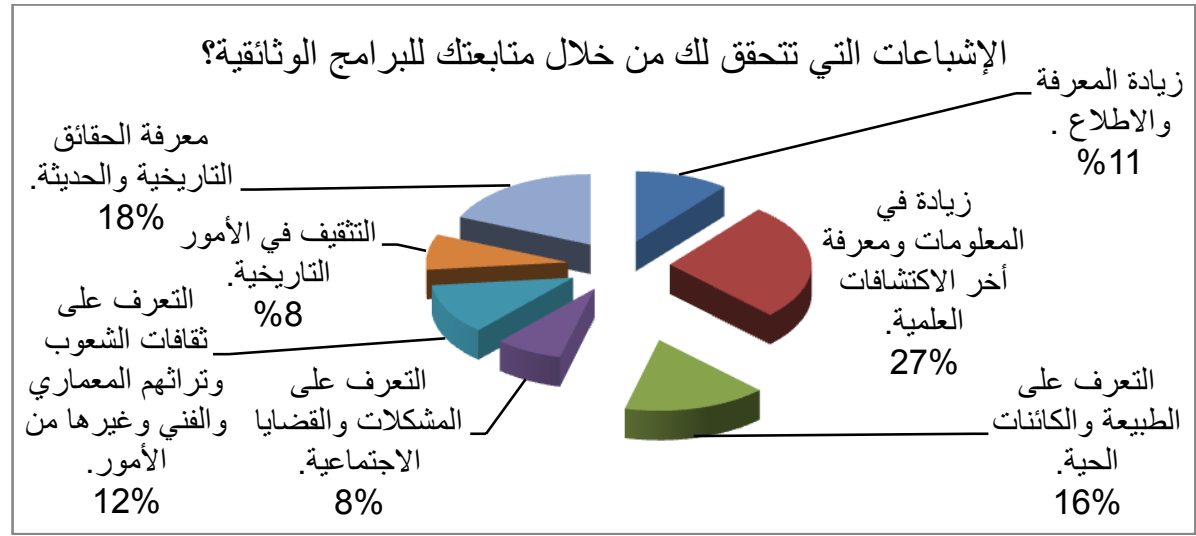

الشكل رقم (12) الإشباعات المتحققة من متابعة البرامج الوثائقية

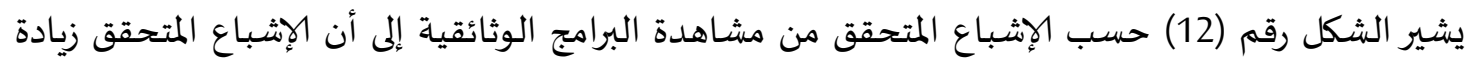
في المعلومات ومعرفة أخر الاكتشافات العلمياة بتكرار بلغ (62) وبنسبة بلغت (26.7\%)، تلتها معرفة الحقائق

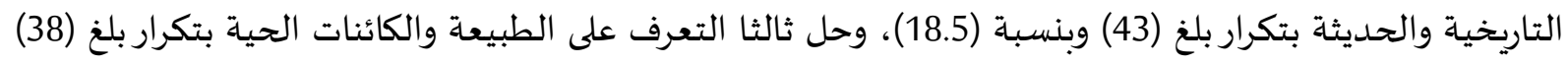

وبنسبة (16.3)، فيما حلت التعرف على المشكلات والقضايا الاجتماعية أخيرا بتكرار (18) وبنسبة (7.7).

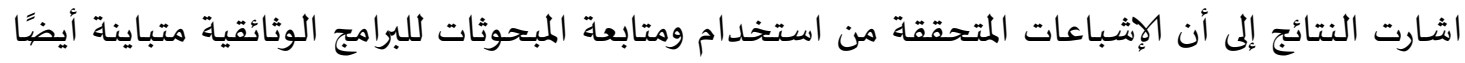

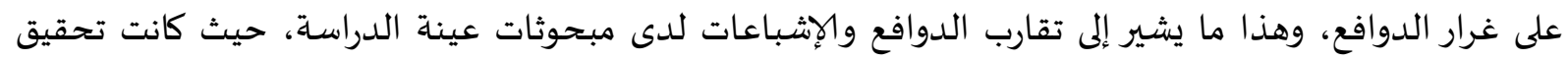

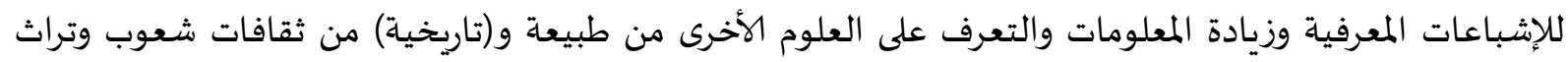

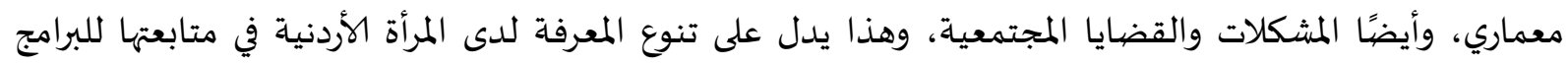
الوثائقي.

المحور الثالث: اتجاهات المرأة الأردنية نحو استخدام البرامج الوثائقية من خلال قناتي الجزيرة الوثائقية

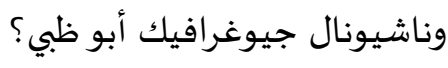
11. اتجاهات المرأة الأردنية نحو استخدام البرامج الوثائقيات من من خلال قناتي الجزيرة الوثائقية وناشيونال

$$
\text { جيوغرافيك أبو ظبي؟ }
$$

الجدول رقم (1) اتجاهات المرأة الأردنية نحو استخدام البرامج الوثائقية من خلال قناتي الجزيرة الوثائقية

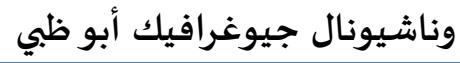

\begin{tabular}{|c|c|c|c|c|c|}
\hline \multicolumn{2}{|c|}{ النسبة المئوية } & \multicolumn{2}{|c|}{ 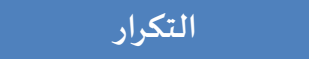 } & \multirow{3}{*}{ السؤال/ الفئة } & \multirow{3}{*}{ i } \\
\hline 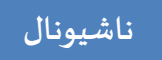 & الجزبرة & 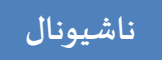 & ال الجزيرة & & \\
\hline جيوغرافيك & الوثائقية & جيوغرافيك & الوثائقية & & \\
\hline 72.4 & 27.5 & 168 & 64 & أي القناتين تفضل مشاهدتها؟ & 1 \\
\hline 74.5 & 25.4 & 172 & 59 & تنوع مواضيع البرامج التي تعرضها & 2 \\
\hline 77.5 & 22.4 & 180 & 52 & متطورة في أسلوب عرضها للبرامج & 3 \\
\hline 72.8 & 27.1 & 169 & 63 & تلبي رغباتك واحتياجاتك & 4 \\
\hline 72.4 & 27.5 & 168 & 64 & تعرض الموضوعات التي تهتمين بمتابعتها & 5 \\
\hline
\end{tabular}




\begin{tabular}{|c|c|c|c|c|c|}
\hline \multicolumn{2}{|c|}{ النسبة المئوية } & \multicolumn{2}{|c|}{ 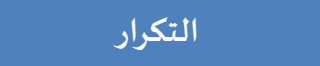 } & \multirow{3}{*}{ 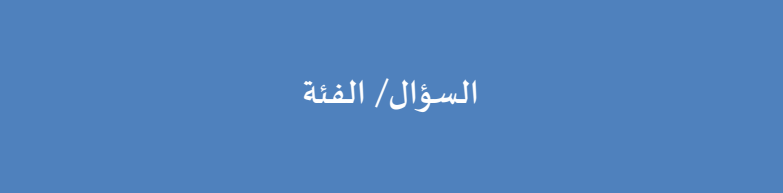 } & \multirow{3}{*}{$\hat{\imath}$} \\
\hline & & 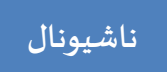 & الجزيرة & & \\
\hline 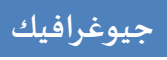 & 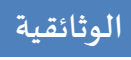 & 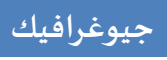 & 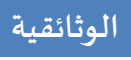 & & \\
\hline 73.2 & 26.7 & 170 & 62 & تسـاهم في تنمية مهاراتك ومعرفتك & 6 \\
\hline 75.4 & 24.5 & 175 & 57 & تعرض لك الوجه الأخر للموضوعات & 7 \\
\hline 72.4 & 27.5 & 168 & 64 & تجذبني لمضمون البرامج التي تتحدث عنها & 8 \\
\hline 80.6 & 19.3 & 187 & 45 & تجذبني لبراعة التصويرودقة الإخراج في العمل & 9 \\
\hline 72.8 & 27.1 & 169 & 63 & أي من هذه القنوات ساهمت في إشباع رغباتك أكثر؟ & 10 \\
\hline 73.7 & 26.2 & 171 & 61 & 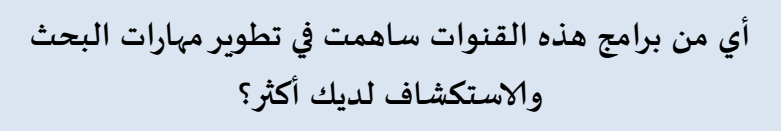 & 11 \\
\hline 74.5 & 25.4 & 173 & 59 & ما القناة التي تحقق لك متعة المشـاهدة؟ & 12 \\
\hline 78.4 & 21.5 & 182 & 50 & $\begin{array}{c}\text { أي من القناتين تستخدم التكنولوجيا المتطورة في الإنتاج } \\
\text { والاتصيال أكثر؟ }\end{array}$ & 13 \\
\hline 10.3 & 89.6 & 24 & 208 & أي من القناتين ترى أنها تستخدم الأسلوب التقليدي في عرضها & 14 \\
\hline
\end{tabular}

تشير بيانات الجدول رقم (1) حسب اتجاهات المرأة الأردنية نحو استخدام البرامج الوثائقية من خلال

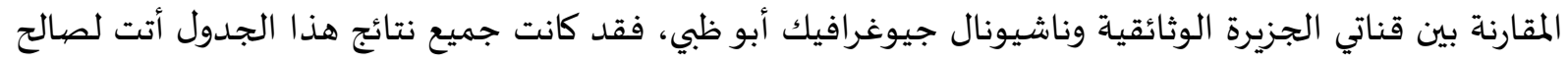

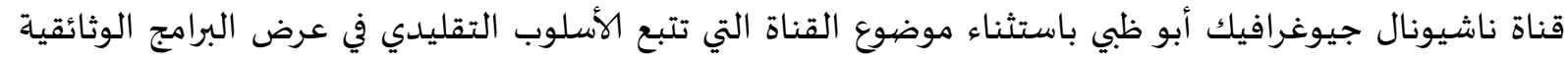

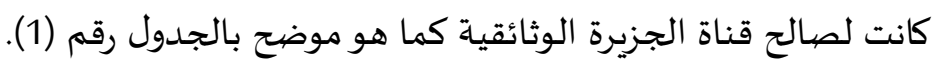

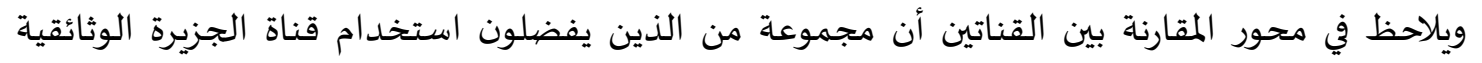

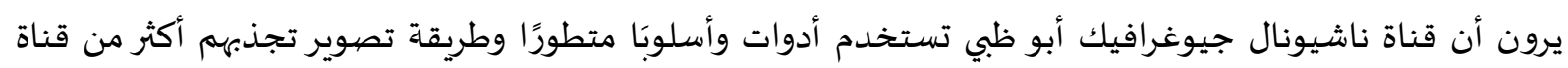

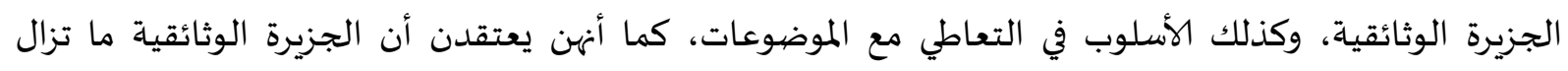
تستخدم أسلوبًا تقليديًا في طرح برامجها.

12. ما نوع البرامج التي تفضلين مشاهدتها على قناة الجزيرة الوثائقية؟ برامبا.

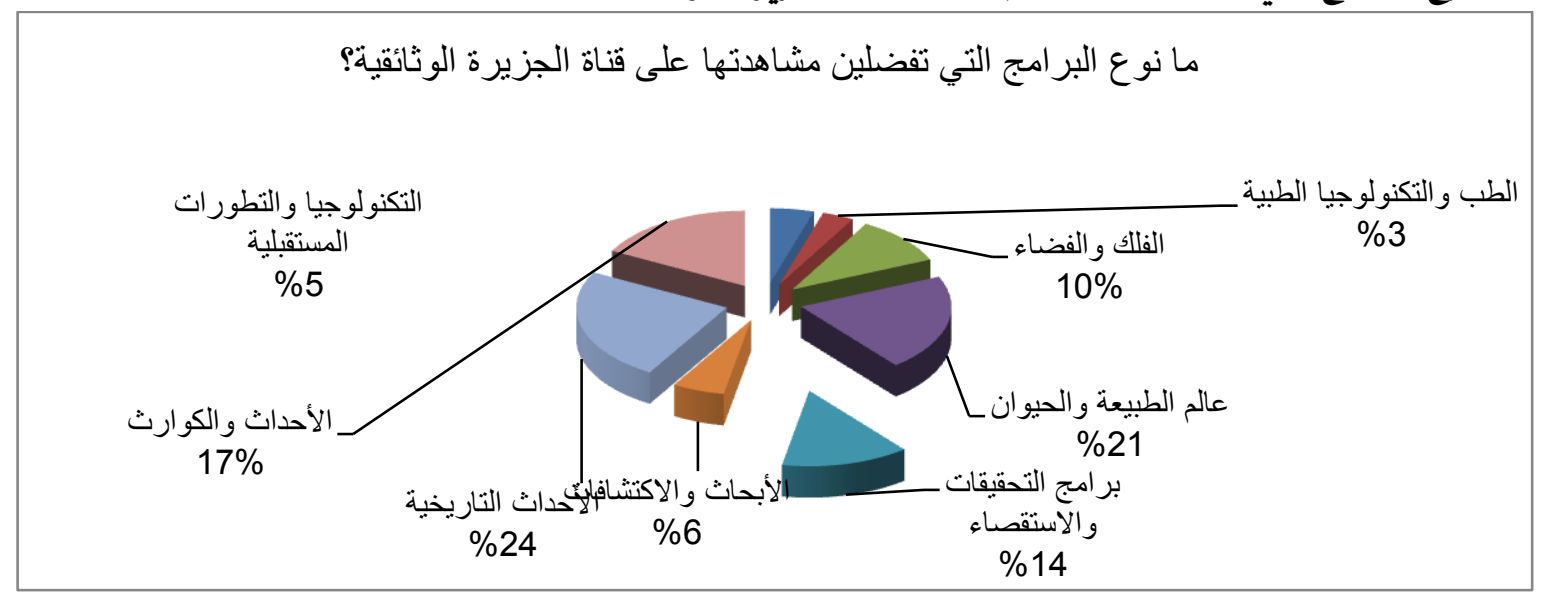

الشكل رقم (13) نوع الرامج المفضلة على قناة الجزيرة الوثائقية 
يشير الشكل رقم (13) حسب نوع البرامج المفضل مشاهدتها على قناة الجزيرة الوثائقية إلى أن نوع البرامج المفضل الأحداث التاريخية بتكرار بلغ (56) وبنسبة بلغت (24.1\%)، ثم برامج عالم الطبيعة والحيوان بتكرار (48) وبنسبة (20.6\%)، تلاها برامج الأحداث والكوارث بتكرار بلغ (40) وبنسبة (17.2\%)، فيما حل أخيرا الطب بتربة

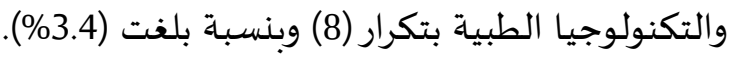
أشـارت هذه النتائج إلى أن عينة الدراسة تفضل ولتهار متابعة البرامج التاريخية والأحداث والكوارث والأبحاث والطبيعة على قناة الجزيرة الوثائقياة، وذا يدل على أن البرامج الوثائقية من هذه النوعية التي تبث على قداة الناة الجزيرة

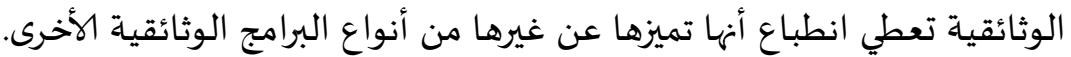

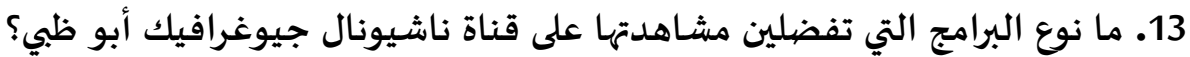

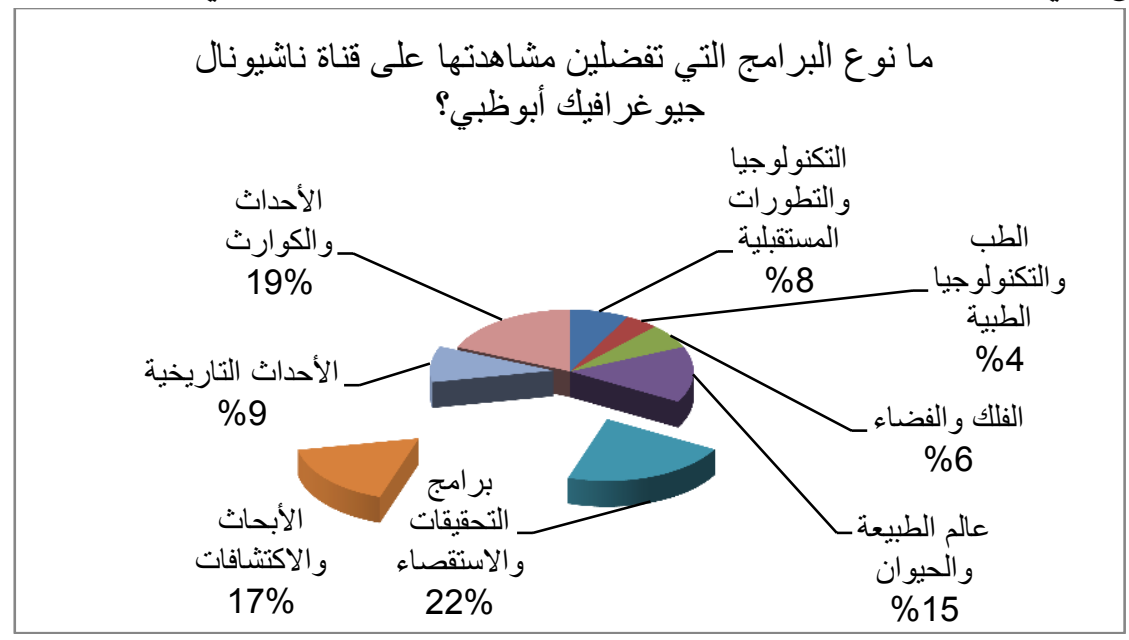

الشكل رقم (14) نوع البرامج المفضلة على قناة ناشيونال جيوغرافيك أبو ظبي

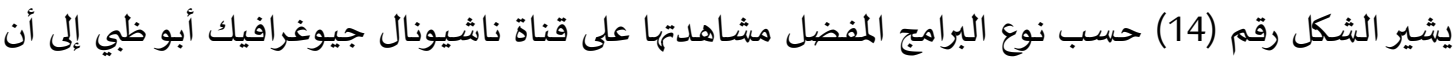

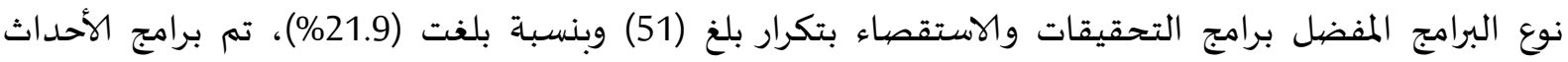

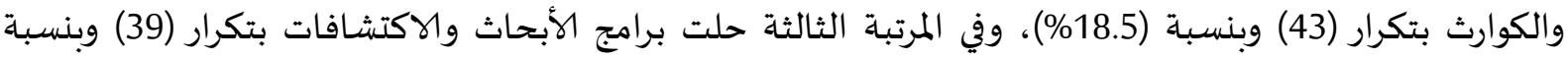

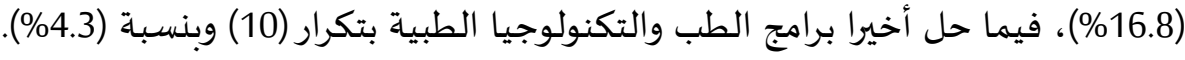

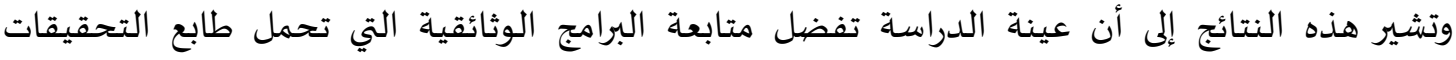

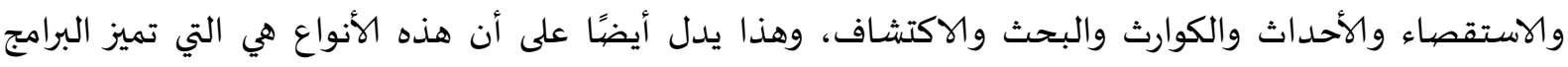

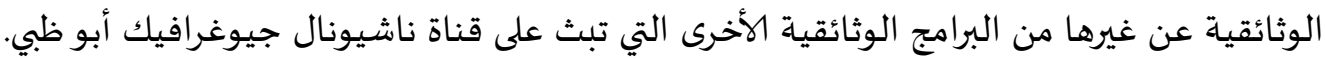

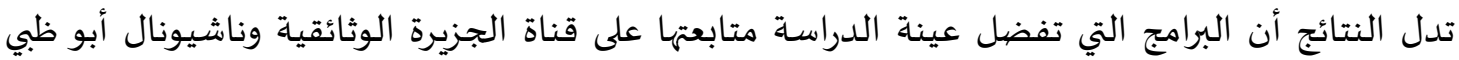

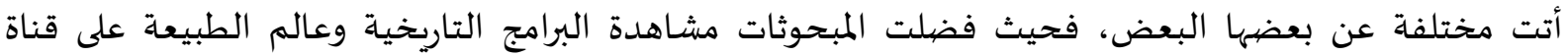

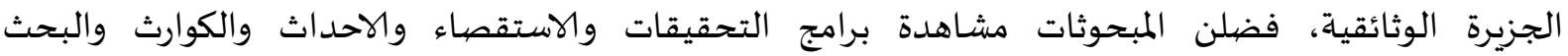
والاكتشاف، أي أن المبحوثات يفضلن برامج التاريخ والطبيعة على قناة الجزيرة الوثائقية وبرامج التحقيقات والكوارث والاكتشاف على ناشيونال جيوغرافيك أبو ظبي.

هالمحور الرابع: الإشباعات والدوافع من استخدام قناتي الجزيرة الوثائقية وناشيونال جيوغرافيك أبو ظبي؟

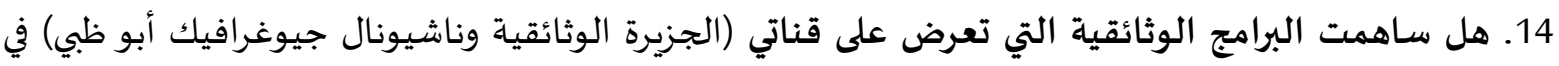




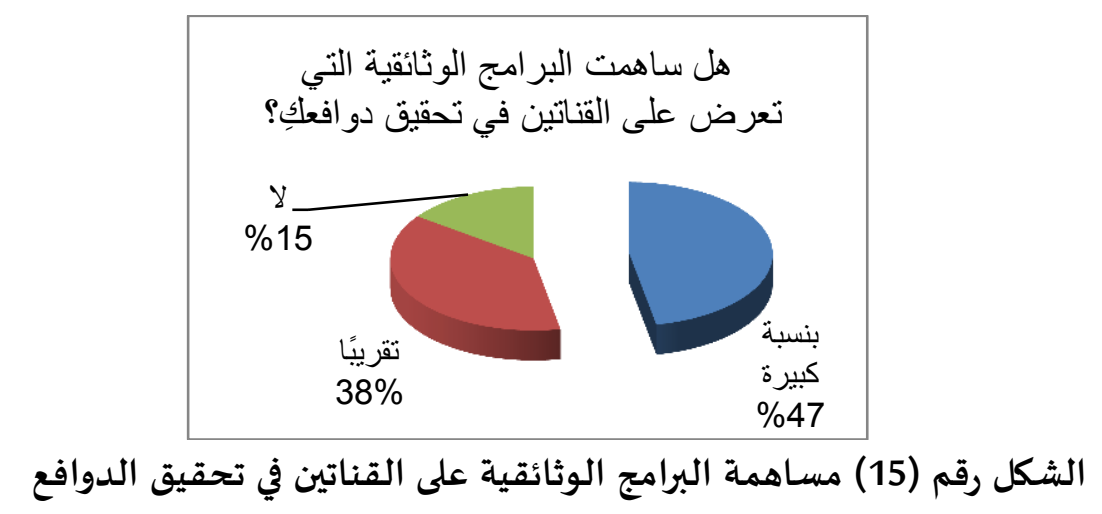

يشير الشكل رقم (15) حسب مساهمة البرامج الوثائقية التي تعرض على قناتي الجزيرة الوثائقية وناشيونال التهال

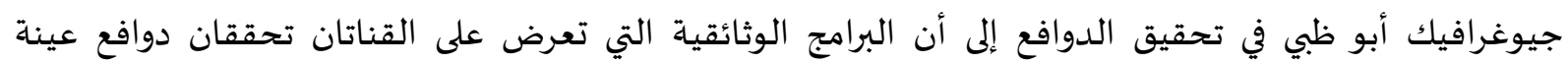

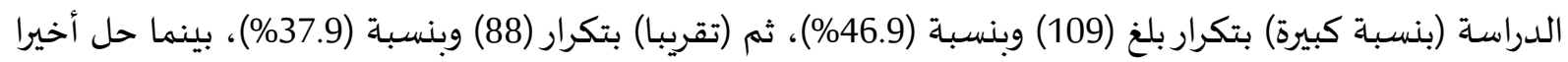
(لا) بتكرار بلغ (35) وبنسبة (15.0\%). أظهرت النتائج أن البرامج الوثائقية التي تعرض على النى قناتي الجزيرة الوثائقية وناشيونال جيوغرافيك أبو ظبي

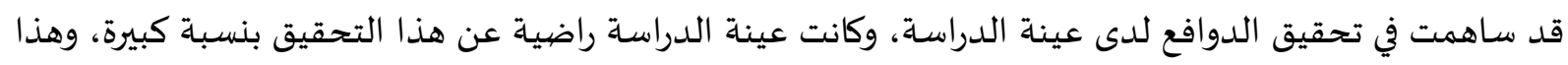

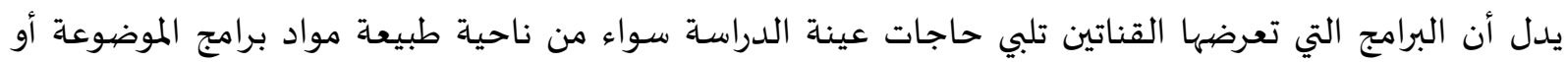
الأساليب الفنية والتقنية التي تستخدمها القناتين في طريقة عرض وبث البرامج، فنسبة الرضاتيا عينة الرضا عن أداء القناتين أتت عالية بشكل كبير. 15. هل تعتقدين أن البرامج الوثائقية التي تعرض على قناتي (الجزيرة الوثائقية وناشيونال جيوغرافيك أبو

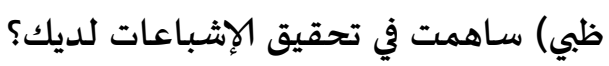

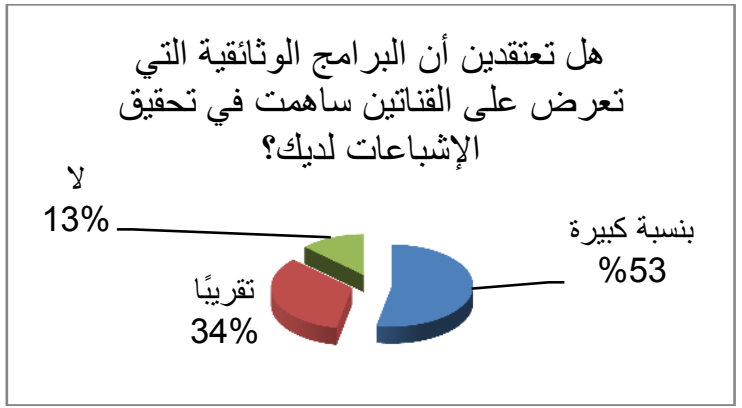

الشكل رقم (16) مساهمة البرامج الوثائقية على القناتين في تحقيق الإشباعات لدى مجتمع الدراسة يشير الشكل رقم (16) حسب أن البرامج الوثائقية التي تعرض على قناتي الجزيرة الوثائقياة وناشيونال

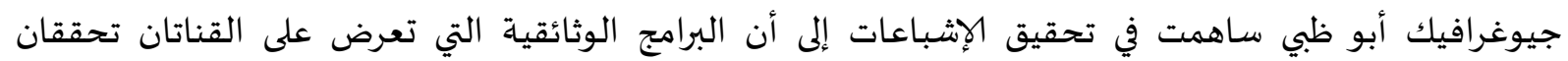
الإشباعات لدى عينة الدراسة (بنسبة كبيرة) بتكرار بلغ (123) وبنسبة (53.0\%)، ثم (تقريبا) بتكرار (79) وبنسبة (34.0\%)، بينما حل أخيرا (لا) بتكرار بلغ (30) وبنسبة (12.9\%).

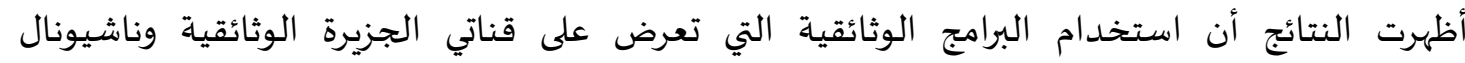

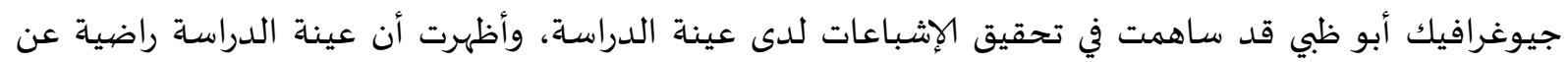

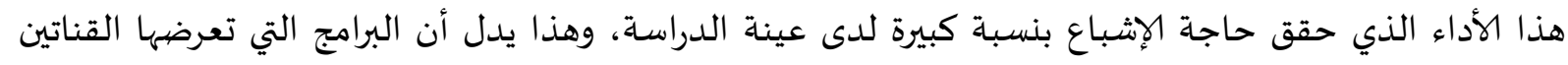

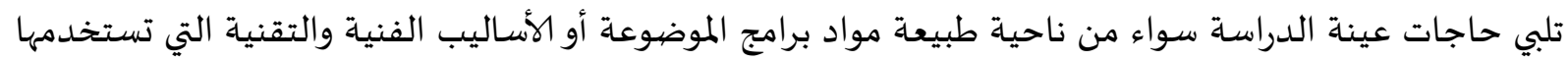
القناتين في طريقة عرض وبث البرامج، فنسبة الرضا عن أداء القناتين أتت عالية بشكل كبية كبير. 
أتت نتائج الدراسة التي تتعلق بأسئلة الدراسة على النحو الآتي:

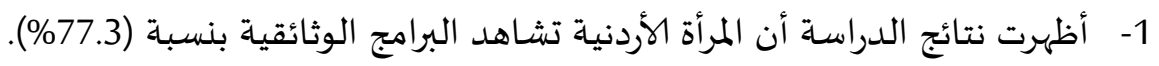

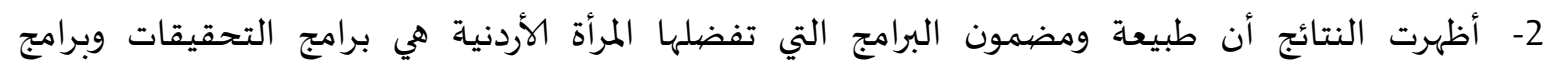
الاستقصاء بنسبة (27.1\%)، ثم برامج الأحداث والكوارث بنسبة (21.5\%)، تلاها برامج عالم المبات الطبيعة

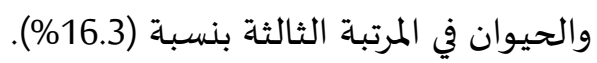

3- أظهرت نتائج الدراسة أن دافع استخدام المرأة الأردنية للبرامج الوثائقية كان للاستزادة في الثقافة العامة في

مختلف العلوم بنسبة (23.2\%)، ثم تلاها تساهم في التعرف أكثر حول الموضوعات المطروحة بنسبة

4- أظهرت النتائج أن الإشباع المتحقق من متابعة المرأة الأردنية للبرامج الوثائقية، كان زيادة في المعلومات

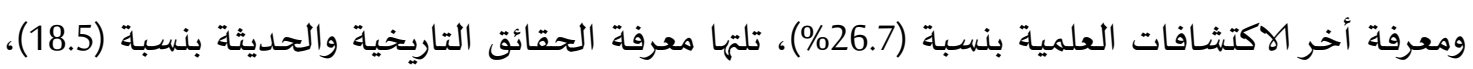

ثم التعرف على الطبيعة والكائنات الحية بنسبة (16.3).

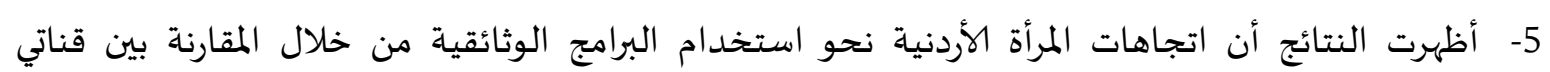

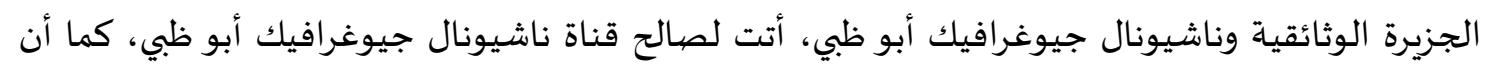

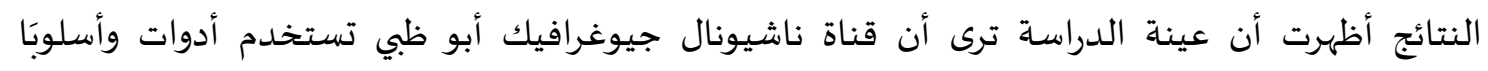

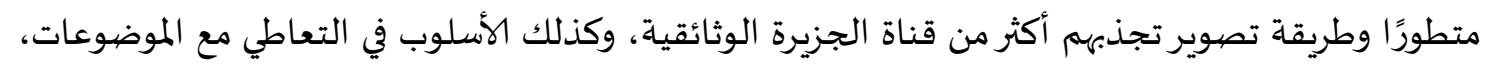

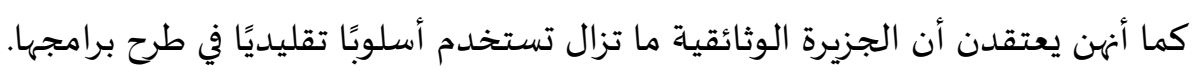

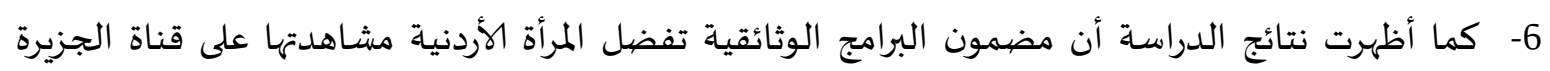

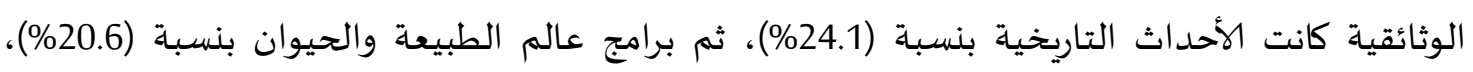

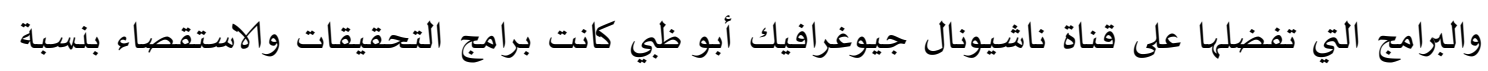
بلغت (21.9\%)، تم برامج الأحداث والكوارث بنسبة (18.5\%).

7- أظهرت النتائج أن البرامج الوثائقية التي تعرض على التهل القناتان تحققان دوافع المرأة الأردنية بنسبة (46.9\%).

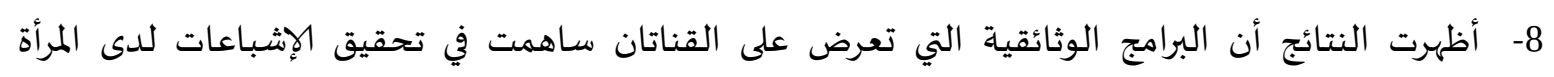
الأردنية بنسبة (53.0\%).

التوصيات والمقترحات.

استنادًا لنتائج الدراسة يوصي البات الباحثان ويقترحان ما يأتي:

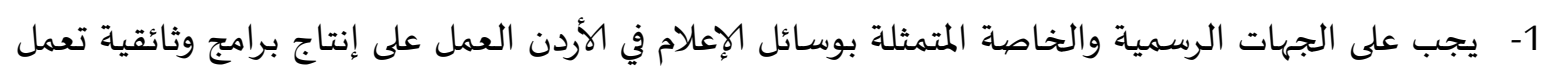

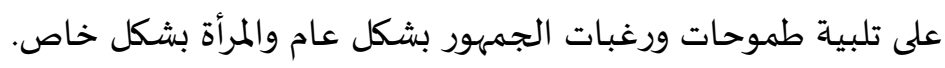

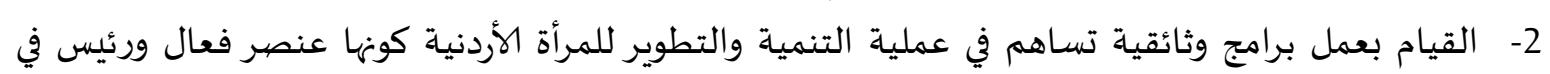
المجتمع 3- يجب على وسائل الإعلام وبالاشتراك مع مراكز الاستطلاع والرأي، عمل القيام بدراسات تعمل على معرفة

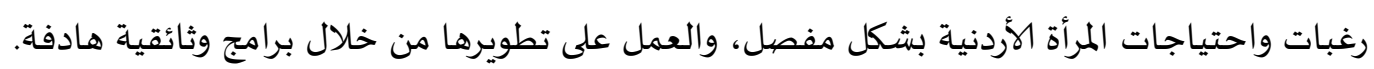

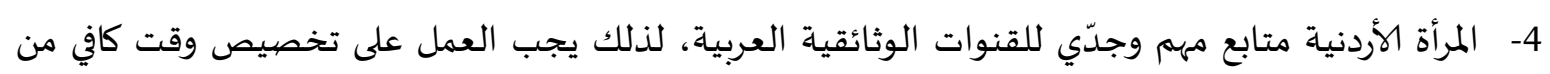

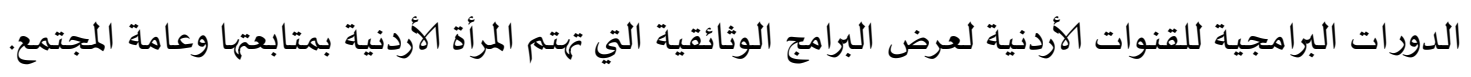


5- نظرًا لعدم وجود دراسات تهتم بدراسة المرأة نحو البرامج الوثائقية محليًا وعربيًا، فإنه من الواجب على

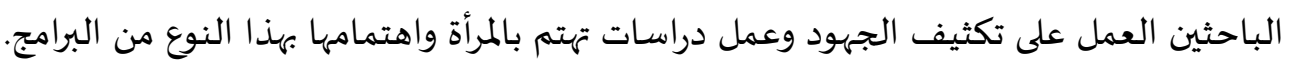

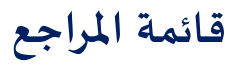

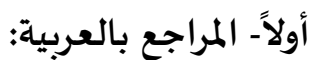

بريك، خديجة. (2009). جمهور البرامج الوثائقية في القنوات الفضائية دراسة في الاستخدامات والإشباع، رسالة

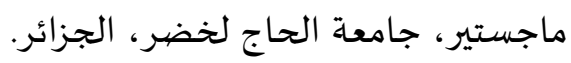

بن شيخ، عبد القادر. (2007). البرامج الوثائقية والتسجيلية في البرمجة التلفزيونية الترنية العربية، مجلة اتحاد إذاعات الدول العربية، عدد 2، تونس. بن عيسى، عسلوان. (2002). وصفة أولية للبرامج الوثائقية العلمية في التلفزيون العربي: أصوات عربية وصور أجنبية ... وتوابل أخرى، عدد 4، مجلة عان اتحاد الاذاعات العربية.

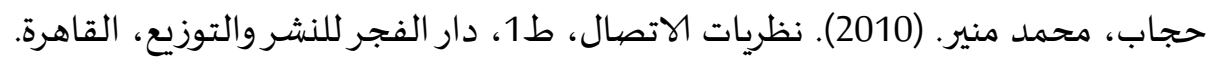
حجاب، محمد، (2006). أساسيات البحوث الإعلامية والاجتماعية، دار الفجر للنشر والتوزيع، القاهرة.

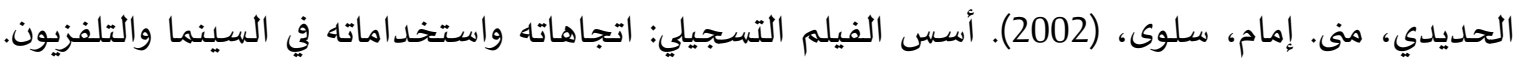
دار الفكر العربي، القاهرة. الحديدي، منى، إمام، سلوى. (2010). السينما التسجيلية الخصائص والأساليب والاستخدامات، ط1، دار الفكر العربي، القاهرة. حسين، سمير. (1999). دراسات في مناهج البحث العلمي، ط 3، دار عالم الكتب، القاهرة. زهران، حامد. (2005). علم نفس النمو: الطفولة والمراهقة، عالم الكتب، القاهرة. سعد الدين، سلوى احمد. (2009). نشأة وتطور الفيلم التسجيلي بنوعياته المختلفة، بحث مقدم المأل الكاديمية الفنون التابع للمعهد العالي للسينما، القاهرة. عبد الحميد، محمد. (2004). البحث العلمي في الدراسات الإعلامية، ط2، عالم العمالي الكتب، القاهرة. العبد، عاطف عدلي، العبد، نهى عدلي. (2008). نظريات الإعلام وتطبيقاتها العربية، دار الفكر العربي، القاهرة. عطا الله، محمود سامي. (1995). الفيلم التسجيلي سلسلة الألف كتاب (188)، الهيئة المصرية العامة للكتاب، القاهرة. - مان.

قاقيش، عدي. (2015). استخدام طلبة الجامعات الأردنية للبرامج الوثائقية والإشباعات المتحققة منها، رسالة ماجستير، جامعة البترا، الأردن.

كولمان، هيلا. (1969). إنتاج الفيلم السينمائي، ترجمة عبد الحليم البشلاوي، مكتبة الوعي العبلة العبي، القاهرة.

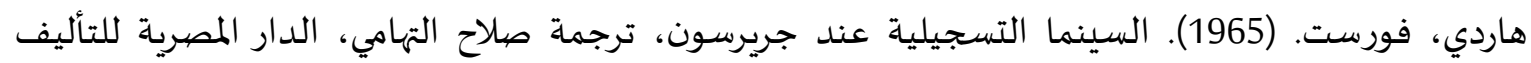

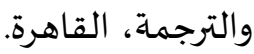

\section{ثانياً - المراجع بالإنجليزية:}

- Barnouw, Erik. (1976). Documentary: A. History of the Nonfiction Film, Oxford University press, London, Oxford, New york.

- Barsamm Richard Meram. (1974). Nonfiction Film. George Allen and Unvin, London. 
- $\quad$ https://ar.wikipedia.org/wiki/\%D8\%A7\%D9\%84\%D8\%AC\%D8\%B2\%D9\%8A\%D8\%B1\%D8\%A9_\% السبت، 14-11- -11 2020, 11:15 20 الساعة.

- $\quad$ https://ar.wikipedia.org/wiki/\%D9\%86\%D8\%A7\%D8\%B4\%D9\%8A\%D9\%88\%D9\%86\%D8\%A7\%D 9\%84_\%D8\%AC\%D9\%8A\%D9\%88\%D8\%BA\%D8\%B1\%D8\%A7\%D9\%81\%D9\%8A\%D9\%83_\%D8 \%A3\%D8\%A8\%D9\%88\%D8\%B8\%D8\%A8\%D9\%8A, الساعة 11:30, 2020-11-14, السبت.

- Reed, H Blake \& Edein O. Haroldsen. (1982) "A Taxonomy of Concept in communication", Arts Books, Hasting Honse publishers, New York.

- Werner, Severin J. \& James, W. (1992). communication theories: origins, the methods and uses in mass media. New York: Hastings Honse publishers. 